OPEN ACCESS

Edited by:

Elena Zenaro,

University of Verona, Italy

Reviewed by:

Douglas F. Nixon,

Cornell University, United States

Hervé Perron

Geneuro Innovation, France

*Correspondence:

Christine Römer

christine.roemer@mdc-berlin.de

Specialty section:

This article was submitted to

Neurodegeneration,

a section of the journal

Frontiers in Neuroscience

Received: 01 January 2021

Accepted: 05 February 2021

Published: 12 March 2021

Citation:

Römer C (2021) Viruses and Endogenous Retroviruses as Roots for Neuroinflammation

and Neurodegenerative Diseases.

Front. Neurosci. 15:648629. doi: 10.3389/fnins.2021.648629

\section{Viruses and Endogenous Retroviruses as Roots for Neuroinflammation and Neurodegenerative Diseases}

\author{
Christine Römer* \\ Max Delbrück Center for Molecular Medicine in the Helmholtz Association, The Berlin Institute for Medical Systems Biology, \\ Berlin, Germany
}

Many neurodegenerative diseases are associated with chronic inflammation in the brain and periphery giving rise to a continuous imbalance of immune processes. Next to inflammation markers, activation of transposable elements, including long intrespersed nuclear elements (LINE) elements and endogenous retroviruses (ERVs), has been identified during neurodegenerative disease progression and even correlated with the clinical severity of the disease. ERVs are remnants of viral infections in the human genome acquired during evolution. Upon activation, they produce transcripts and the phylogenetically youngest ones are still able to produce viral-like particles. In addition, ERVs can bind transcription factors and modulate immune response. Being between own and foreign, ERVs are reviewed in the context of viral infections of the central nervous system, in aging and neurodegenerative diseases. Moreover, this review tests the hypothesis that viral infection may be a trigger at the onset of neuroinflammation and that ERVs sustain the inflammatory imbalance by summarizing existing data of neurodegenerative diseases associated with viruses and/or ERVs.

Keywords: HERV, LINE, virus, neurodegeneration, neuroinflammation

\section{INTRODUCTION}

Viruses have long been linked with diseases of the nervous system. Several viruses, including human $\alpha$-herpesvirus types 1, 2, and 3 (HHV-1 and HHV-2, known as herpes simplex viruses, and HHV3 , known as varizella zoster virus), human cytomegalovirus (CMV), human immunodeficiency virus (HIV), Epstein-Barr virus (EBV), Ebola virus, and rabies virus are capable of reaching the central nervous system (CNS) (Dando et al., 2014). Often, particular viral nucleic acids or proteins are found in the brain, cerebrospinal fluid (CSF), or peripheral blood of patients with a certain neurological disease. For example, HHV-3 and HHV-6 are present in the CSF (Mancuso et al., 2007; Alvarez-Lafuente et al., 2008), coronaviruses in the CNS of multiple sclerosis (MS) patients (Burks et al., 1980), and HIV and human T-cell leukemia virus-1 (HTLV-1) in the brains of amyotrophic lateral sclerosis (ALS) patients (Verma and Berger, 2006). HHV-6A DNA and transcripts, in turn, are increased in the brains of Alzheimer's disease (AD) patients and closely correlate with neuronal loss (Readhead et al., 2018). Tracing neuropathologies to viral infections can, however, be challenging. This holds particularly true when the virus becomes "slower" or "latent" following acute infection (Sigurdsson, 1954; Murphy and Yunis, 1976; Steiner et al., 2007; 
Kennedy and Cohrs, 2010; Shu et al., 2015; Rodriguez et al., 2020). The tremendous research from the beginning of the HIV pandemic has greatly enhanced evidence and understanding of this slow action of viruses in the CNS (Garcia et al., 1999). Important to consider also is the long-term risk from accumulated infections during a lifetime that might lead to a cumulative and individual risk of developing neuropathology, such as stroke and dementia (Almeida and Lautenschlager, 2005; Ruprecht et al., 2006; Tai et al., 2009; Sico et al., 2015).

More recent research has shown that viruses, such as HIV, EBV, CMV, influenza, herpesviruses, and HTLV-1 can activate viral sequences originating from retroviral infections in the distant past of human evolution that have been incorporated into the human genome (Nellaker et al., 2006; Toufaily et al., 2011; Young et al., 2012; Leboyer et al., 2013; Li et al., 2014; Kury et al., 2018). While their ability to express viral products is mostly lost, some of these endogenous retroviruses (ERVs) have evolved to play important roles in physiological processes, such as placentation, early human embryogenesis, neurodevelopment, and immune response regulation (Kammerer et al., 2011; Wang et al., 2014, 2020; Chuong et al., 2016; Romer et al., 2017; Xue et al., 2020). Activation of ERVs, such as by exogenous viruses or environmental factors, can contribute to a multitude of neurodevelopmental, neurodegenerative, and neuroinflammatory disorders (Balestrieri et al., 2019; Gruchot et al., 2019, 2020; Tam et al., 2019; Evans and Erwin, 2020; Groger et al., 2021), including HIV-associated neurodegenerative disorder (HAND), AD, MS, ALS, schizophrenia, stroke, and neuropathogenesis of severe acute respiratory syndrome coronavirus-2 (SARS-CoV-2) as well as to accelerated neurological decline in aging.

This review highlights the interplay between endogenous viruses and retroelements, on the one hand, and exogenous viruses, on the other hand, and aims at revealing underlying mechanisms in aging, and neurodegenerative and neuroinflammatory diseases summarizing recent advances in this field.

\section{VIRAL INFECTION OF THE CENTRAL NERVOUS SYSTEM}

The central nervous system (CNS) is not a common target organ for viruses. It is neither easily accessible nor as advantageous in terms of contagiousness and successful viral transmission to new hosts as the respiratory or gastrointestinal tract. Shielded by the meninges, CSF, and blood brain barrier (BBB), the CNS is immunologically unique and privileged (Louveau et al., 2015). Although the CNS itself is armed with an array of immunological mechanisms, including support from the periphery, it may be considered as a sanctuary where viral replication occurs despite a complete viral suppression in the peripheral blood. This has been shown, for example, for the HIV (Walker et al., 2008). In addition to viruses with neurotropism, only minor mutations may be sufficient to create viruses that can access the CNS via various routes (Wiley, 2020). Permeability of the BBB may be increased by high viremia accompanied by elevated cytokine levels and also by direct interaction with tight junction proteins (Toborek et al., 2005; Chai et al., 2014). Viruses can infect endothelial cells of the $\mathrm{BBB}$, allowing viral replicates to be released into the CNS (Verma et al., 2009; Fletcher et al., 2012), while infection of leukocytes or monocytes by, for example, HIV and SARS-CoV-2, that pass BBB physiologically, provides a "trojan-horse" mechanism to enter the CNS (Larochelle et al., 2011; Takeshita and Ransohoff, 2012; Bostanciklioglu, 2020). Attention is currently drawn to the CNS invasion through retrograde neuronal transport of infected peripheral nerve afferents, as SARS-CoV-2 and other coronaviruses are associated with CNS entry via the olfactory pathway, a mechanism that has been also described for other viral families such as influenza A virus, rabies virus, and herpesviruses (van Riel et al., 2015), and other peripheral nerves, for example, the sciatic nerve and vagus nerve (Ren and Racaniello, 1992; Ohka et al., 1998; Guadarrama-Ortiz et al., 2020; Liu et al., 2020). Figure 1 depicts the mechanisms of viral entry into the CNS.

Once in the CNS, acute infections present with encephalitis, myelitis, or viral meningitis. Generally, virus-triggered immune reaction is limited in time and ends with the virus being combated; however, certain neurotropic viruses can continue to elicit progressive damage on brain structure, function, and cognition long after the clearance of virus from the peripheral blood. In addition to this type of chronic infections, viruses can enter a latent (dormant) phase, interrupted by occasional full awakening of the virus. Sometimes, the same virus can contribute to both. This is the case for the HIV (Rodriguez et al., 2020), measles morbillivirus (Murphy and Yunis, 1976), HHV-1 (Shu et al., 2015), and HHV-3, to name a few (Steiner et al., 2007; Kennedy and Cohrs, 2010). The high worldwide seroprevalence of some of these viruses, such as that of HHV1 and HHV-2 being around 90\% (Wald and Corey, 2007), indicates that facilitating factors must exist that ultimately decide upon disease development. In consideration are comorbidities such as traumas to latently infected neurons (Zhang et al., 2013), immune-depriving conditions such as AIDS (Rodriguez et al., 2020), leukemia (Koskenvuo et al., 2008; Lancman et al., 2020), or stroke-induced immunodepression (Deroux et al., 2012; Hetze et al., 2013; Romer et al., 2015; Bertrand et al., 2019), and cumulative infectious burden (Sico et al., 2015), and also environmental factors (Liu et al., 2013; Brutting et al., 2018; Mueller et al., 2018; Del Re and Giorgi, 2020). The role of aging as a facilitating factor and the interplay with ERVs are discussed in detail below.

\section{ENDOGENOUS RETROVIRUSES AND RETROELEMENTS}

Exogenous retroviruses from which ERVs originate, like other retroviruses, contain single-stranded (ss) anti-sense RNA and RNA reverse polymerase to generate double-stranded DNA (dsDNA). With the help of the retroviral integrase, this DNA copy may become endogenized into the host genome, essentially when infecting gametes (germ cells) with chromosomal insertion sites that will allow the birth of viable offspring over generations. Over the evolution, this type of infections and endogenizations 


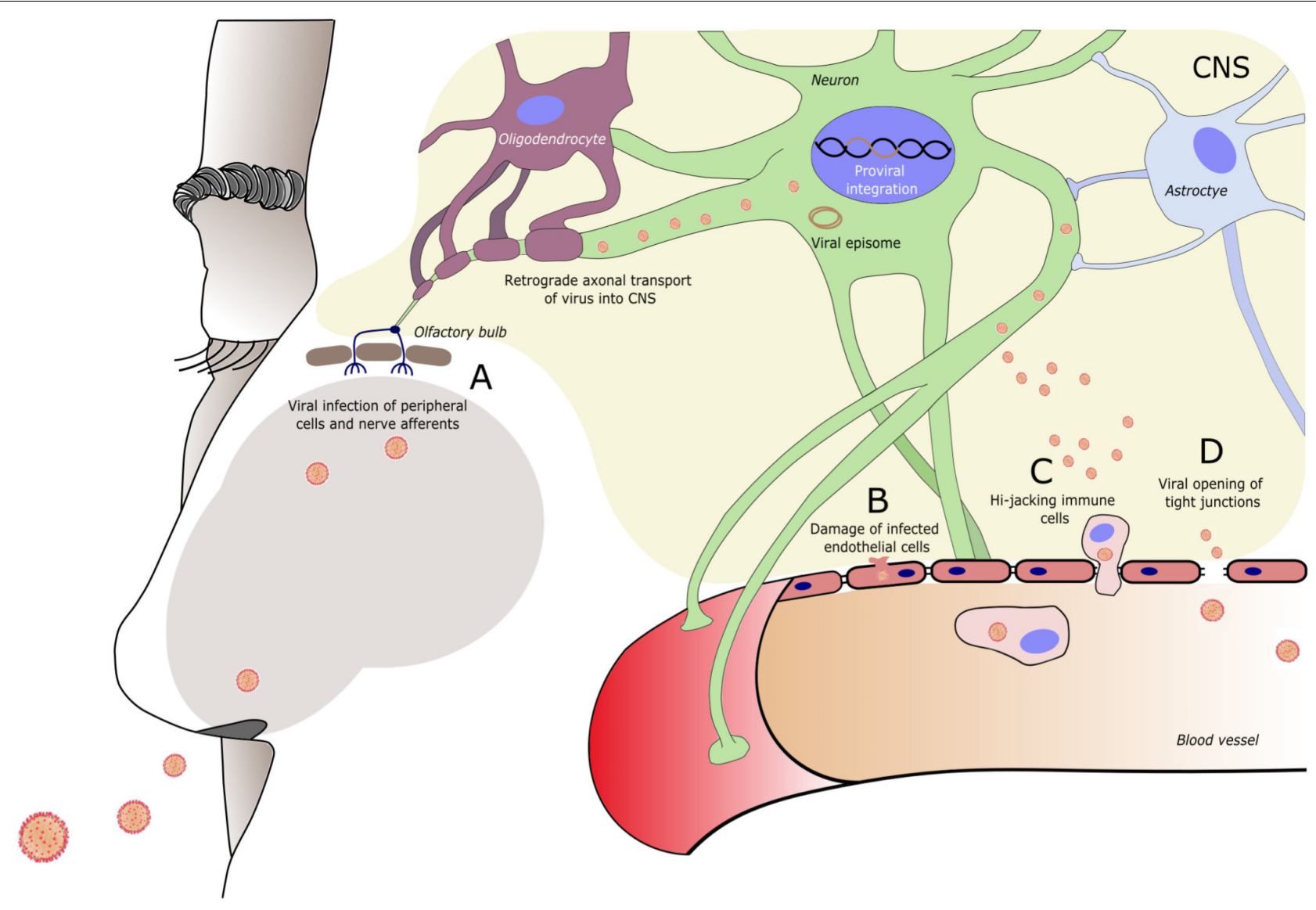

FIGURE 1 | Entry routes of exogenous viruses into the central nervous system (CNS). Virus can enter the CNS via (A) Peripheral nerve terminals (in this example of the olfactory nerve) and retrograde axonal transport. (B) Infection of and damage to endothelial cells of the blood brain barrier (BBB). (C) Infection of circulating immune cells that travel across the BBB. (D) Modulation of tight junction molecules of the BBB, increasing BBB permeability. A specific entry route can be typical for a specific virus, however, often more than one route is used. Entry route may vary during the course of infection (e.g., BBB damage in conditions of high viremia) and new CNS entry mechanisms can follow when the viral genome sustains mutational changes. A neurotrophic virus often infects specific cell types within the CNS. Reaching the CNS enables the virus to circumvent the peripheral immune response. To evade also the CNS immune response, viruses may enter a dormant state forming a viral episome or integrating into the host cell DNA.

of retroviruses have occurred multiple times (Kozak, 1985). Gradually, ERVs become non-infectious, lose the ability to exit the host cell, and adopt the nature of transposable elements. ERV sequences become transpositionally inactive, mutated, degraded, and epigenetically silenced as part of the host control in protection of genome stability. ERV sequences take up about $8 \%$ of the modern human genome (Gannet, 2019). ERV families that have been less prone to be degraded by the host, such as human ERV H (HERV-H) and HERV-K, have shaped the evolution and complexity of innate and adaptive immune pathways (Villarreal, 2011; Chuong et al., 2016, 2017). Regulation mechanisms to control the HERV activity, mainly via epigenetics (for example, cytosine methylation) form the basis for proper host-HERV interaction in controlling vital processes (Lavie et al., 2005; Turelli et al., 2014). The Krüppel-associated box domain (KRAB)associated protein-1 (KAP1)-mediated silencing continues to be the key mechanism of ERV control in adult brain (Fasching et al., 2015). KAP1 deletion during brain development is lethal, and heterozygous deletion of KAP1 causes behavioral changes resembling those observed in human psychiatric conditions associated with HERV upregulation (Jakobsson et al., 2008).

Long interspersed nuclear elements (LINEs) are a group of non-LTR (long terminal repeat) retroelements that compose up to $21 \%$ of the human genome (Gannet, 2019). LINE-1 elements are a major source of structural polymorphisms in humans (Hancks and Kazazian, 2012). Higher LINE-1 activity is characteristic to brain areas of adult neurogenesis, in particular to the hippocampal dentate gyrus (Baillie et al., 2011; Kurnosov et al., 2015; Bachiller et al., 2017) and to human neural progenitor cells (Coufal et al., 2009). LINE-1 insertions often locate at neuronal genes, and LINE-1 activity can initiate neuronal differentiation (Muotri et al., 2005). Hippocampal LINE-1 activity and genomic mosaicism are involved in cognitive processes such as memory formation (Bachiller et al., 2017).

Alu family is the most common member of the short interspersed nuclear elements (SINEs) and accounts for about $13 \%$ of the human genome (Gannet, 2019). Alu elements are actively transposing. However, they do not encode a 
functional reverse transcriptase protein and therefore rely on the machinery of other retroelements, especially LINEs (Wei et al., 2001; Dewannieux et al., 2003). Alu elements are involved in neurogenesis, brain connectome development, and in shaping cognition networks (Mehler and Mattick, 2007; Baillie et al., 2011; Bedrosian et al., 2016).

HERVs, LINEs, and Alus regulate gene expression networks at multiple levels, providing a rich pool for RNA diversification (Lev-Maor et al., 2003; Laperriere et al., 2007; Fujii, 2010; Gim et al., 2014; Goke and $\mathrm{Ng}, 2016$ ), functioning as promoters and enhancers (Norris et al., 1995; Shen et al., 2011; Lee, 2012; Wu et al., 2013; Romer et al., 2017), and coordinating $3 \mathrm{D}$ genomic arrangements via topologically associated domains (Dixon et al., 2012; Zhang et al., 2019). These elements contribute significantly to defining neurobiological processes, including neuronal mosaicism and shaping brain development (Coufal et al., 2009; Baillie et al., 2011; Richardson et al., 2014; Bodea et al., 2018). Alteration of these networks are associated with neurodevelopmental, neurodegenerative, neuroinflammatory, and autoimmune diseases. HERVs, LINE, and Alu elements are subject to a multitude of environmental factors and xenobiotics, which can activate normally well-controlled HERV expression, such as hypoxia (Brutting et al., 2018), drugs (aspirin, caffeine, and valproic acid) (Diem et al., 2012; Liu et al., 2013), and hormones (Norris et al., 1995; Mueller et al., 2018). Also, LINE-1 retroelement activity is sensitive to a multitude of factors including social isolation stress, heavy metals, and antiinflammatory and psychoactive drugs (Del Re and Giorgi, 2020). Together, (H)ERVs, LINE, and Alu elements regulate early human embryogenesis, neurodevelopment, neural diversity, and plasticity. All three are subject to a number of environmental factors, affecting a healthy brain.

\section{INTERPLAY BETWEEN ENDOGENOUS AND EXOGENOUS VIRUSES}

Inherent ERVs and exogenous viruses, being distant relatives, share common mechanisms but can also be opponents. When viruses first try to enter a cell, HERV, coming from inside the host genome, can provide protection by blocking the cellular receptors relevant for the exogenous retrovirus entry (Spencer et al., 2003). ERVs can protect against exogenous retroviral infections by receptor interference if both viruses share the specificity of the env glycoprotein (Weiss et al., 1985). Substantial similarity between HERV and exogenous retrovirus, such as that between HERV-K (HML-2) gag and HIV gag, could lead to fusion of viral proteins and production of defective viral particles (Monde et al., 2012). In addition, HERV antisense transcripts can interact with complementary exogenous retrovirus transcripts to block viral replication and generate dsRNA to be recognized as a pathogen-associated molecular pattern (PAMP) by the host immune system (Tang et al., 2012; Shekarian et al., 2017). Sensing PAMPs, such as viral proteins and nucleic acids, and danger-associated molecular patterns (DAMPs) derived from damaged cells, are part of the innate immune response. Cytoplasmic sensors for viral DNA include cyclic GMP-AMP synthase (cGAS), Z-DNA-binding protein 1 (ZBP1), and TLR9 (Rigby et al., 2014; Hayashi et al., 2015; Xia et al., 2016; Sandstrom et al., 2017; Jiao et al., 2020). Viral RNA are sensed by TLR8 (Heil et al., 2004), TLR3, melanoma-differentiated-associated gene 5 (MDA5), ZBP-1 (Gurtler and Bowie, 2013; Jiao et al., 2020), and retinoic acid inducible gene I (RIG-I) (Gurtler and Bowie, 2013). Innate immune response to viral infections leads to pro-inflammatory cytokine, chemokine, and type I interferon (IFN) release to stimulate adaptive immune response, the $\mathrm{T}$ lymphocyte-mediated cellular and B lymphocyte-mediated humoral immunity.

Activated innate and adaptive immune system cells both can stimulate ERV transcription (Bannert and Kurth, 2004). Generally, immune reactions are limited in time and cleared by the immune system. However, HERVs are continuously present and, under certain conditions, also continuously active. Aiming at clearing up the infection triggered by HERVs, TLR stimulation can, via IFN release, actually activate HERVs further (Bannert and Kurth, 2004). Dispersed at relevant immune genes, activated HERVs and in particular the polymorphic HERV-K (HML-2) loci, form another layer of immune response regulation (Nexo et al., 2011). Certain HERV insertions function as IFN-inducible enhancers, and type I IFN is one of the main innate immune response products to viral infection (Chuong et al., 2016). Neuroinflammation will awaken and activate HERVs in the human brain (Johnston et al., 2001; Manghera et al., 2015, 2016). In this feedback loop, HERV activity is upregulated by anti-viral immune response through inflammatory mediators and also by epigenetic dysregulation (Manghera and Douville, 2013; Hurst and Magiorkinis, 2015, 2017), leading to chronic stimulation of the immune system (Hurst and Magiorkinis, 2015, 2017; Grandi and Tramontano, 2017; Mameli et al., 2017; Ramasamy et al., 2017). Continuous ERV activation is associated with sustained neuroinflammation and predisposes to neurodegenerative and autoimmune diseases (Nexo et al., 2011).

Activation of ERV transcription can directly be achieved by several exogenous viruses, such as HIV, EBV, CMV, influenza, and herpesviruses, some of which can even induce a self-sustained HERV activation (Nellaker et al., 2006; Young et al., 2012; Leboyer et al., 2013; Li et al., 2014; Kury et al., 2018). Among exogenous retroviruses, HTLV-1 Tax can increase HERV-H, HERV-K, HERV-W, and HERV-E expression in T lymphocytes (Toufaily et al., 2011). HIV transactivator of transcription (Tat) protein can stimulate expression of HERV-K and HERV-W in astrocytes and peripheral blood cells and that of HERV-W also indirectly via TLR4 and proinflammatory cytokine (TNF$\alpha$, NF- $\mathrm{B}$ ) production (Uleri et al., 2014). Using mimicry, HIV rev, which mediates nuclear export of HIV messenger RNA (mRNA), also mediates the nuclear export of HERV-K mRNA, thereby promoting HERV-K translation (O'Carroll et al., 2020). Exogenous viruses can further facilitate expression of endogenous superantigens, linked in particular with the CNSaffecting autoimmune diseases (Acha-Orbea, 1992). This occurs, for example, between rabies virus and HERV-W (Lafon et al., 1992; Perron et al., 2001; Lafon et al., 2002) and between EBV and HERV-K18 (Sutkowski et al., 2001). In turn, ERVs may assist 
their exogenous counterparts to escape immune surveillance, repair defects in exogenous retroviruses (Schwartzberg et al., 1985), and facilitate chronic viral replication (Rasmussen, 1997). Also, transcriptionally active ERVs provide a rich pool for recombinational events with exogenous retroviruses. When a host cell is infected by two different viruses, heterologous transactivation can take place where transcription of one virus is initiated by factors produced by the other virus. When ERVs provide envelope glycoproteins to exogenous retroviruses, these could establish a new host cell repertoire and circumvent immune system response (Lusso et al., 1990). A certain degree of epitope similarity between ERV and exogenous retrovirus can lead to a weaker immune response against this virus (Miyazawa and Fujisawa, 1994).

Similar interplay between endogenous retroviruses and exogenous viruses exists in the periphery and may pave way to chronic inflammation. In fact, viruses and endogenous retroviruses have been linked with autoimmune disease pathology, such as systemic lupus erythematosus (Ogasawara et al., 2000; Moon et al., 2004), rheumatoid arthritis (Herve et al., 2002), and diabetes (Levet et al., 2017, 2019). Continued upregulation of HERV-H and HERV-K after the clearance of hepatitis $\mathrm{C}$ virus from the peripheral blood of chronic hepatitis $\mathrm{C}$ patients was recently associated with higher risks for cancer and autoimmunity in these patients (Tovo et al., 2020).

Peripheral inflammation can reach the brain via transversal of circumventricular organs, peripheral nerves, or through proinflammatory cytokine influx upon direct cytokine-endothelial interactions, resulting in reduced BBB integrity (Toborek et al., 2005; Chai et al., 2014). Moreover, peripheral inflammation processes can trigger major neurological events such as stroke via platelet aggregation, hypercoagulation, impaired endothelial function, and thrombosis (Elkind et al., 2020; Oxley et al., 2020).

Figure 2 draws common mechanisms in the interplay of exogenous and endogenous retroviruses leading to sustained neuroinflammation and subsequent CNS damage.

\section{VIRAL AND ENDOGENOUS RETROVIRAL ASSOCIATED PATHOLOGIES}

Table 1 summarizes exogenous viral and endogenous retroviral disorders discussed in the following sections.

\section{HIV-Associated Neurodegenerative Disorder}

HIV infection causes acquired immunodeficiency syndrome (AIDS) affecting multiple systems in the body. One of the complications of HIV infection is the HIV-associated neurodegenerative disorder (HAND) (Navia et al., 1986), which can develop into HIV-associated dementia (Nookala et al., 2017), the most common cause of dementia in young adults (Janssen et al., 1992) with higher prevalence among women (Duarte et al., 2020). HIV is transported to the brain with infected T-lymphocytes and monocytes (Wiley et al., 1986; Takahashi et al., 1996). These long-lived cells are referred to as sources of HIV chronic infection (Nookala et al., 2017). In the brain,
HIV infects primarily the immunocompetent cells, perivascular macrophages, and microglia where it replicates (Watkins et al., 1990; Albright et al., 2000). HIV persists in the CNS, causing motor, cognitive, and behavioral deficits, which can be further aggravated by opportunistic infections by CMV, EBV, HHV-3, and HHV-6 (Almeida and Lautenschlager, 2005).

Neurodegeneration characteristic to HAND emanates from chronic inflammation, sustained by activated monocytes, macrophages and astrocytes, and neurotoxic HIV viral proteins (Ghafouri et al., 2006; Kraft-Terry et al., 2010). These include HIV Tat, HIV viral protein R (Vpr), and HIV env glycoprotein gp160 cleaved product gp120. HIV viral proteins induce neuropathology by aberrant calcium signaling, mitochondrial damage, oxidative stress, excitotoxicity, and inflammation (Nookala et al., 2017), collectively leading to neuronal death (Masliah et al., 1992).

Further augmentation of neurodegeneration and neuroinflammation in HAND comes from HIV and infectioninduced cytokines' (IL-6, IL-1 $\beta$, TNF- $\alpha$, and IFN- $\gamma$ ) ability to dynamically activate HERVs, such as HERV-W (Uleri et al., 2014) and HERV-K (Bhardwaj et al., 2014; O'Carroll et al., 2020). In particular, HIV induces HERV-K transcription and can trigger adaptive immune response against the HERV-K capsid protein (de Mulder et al., 2017). A distinct temporal pattern between HIV and HERV-K activation has been observed in the brains of HIV-infected individuals, demonstrating increased HERV-K activation ahead of spikes in HIV replication in the peripheral blood (Contreras-Galindo et al., 2007) and ahead of clinical symptoms of neurocognitive impairment (Douville and Nath, 2017). HIV-associated motor neuron disease affecting upper and lower motor neurons is likewise escorted by increased HERV-K expression at the onset of neurological symptoms (Bowen et al., 2016). HIV can directly facilitate HERV-K expression, transcript transportation to cytoplasm, and viral particle production (O'Carroll et al., 2020) and regulate antiviral gene expression through activating (H)ERV promoters (Srinivasachar Badarinarayan et al., 2020). Increased HERV-K env expression in cortical neurons of HIV-infected individuals has been linked with restricting HIV replication in these cells (Bhat et al., 2014). In the long term, however, neuronal HERV-K expression leads to neurite retraction and neuronal death (Dembny et al., 2020), in line with HAND. The antiretroviral therapy against HIV is effective also against HERV-K (Bowen et al., 2016). Overall, the neuropathology induced by HIV and HERV-K might have a certain overlap and is difficult to separate. It might be beneficial to monitor the level of HERV-K within the course of HAND.

Of note, incidence of HIV-associated dementia has reduced threefold after the combination antiretroviral therapy became available (Lawrence and Major, 2002). New medical concerns involve premature aging-related neurocognitive disorders (Robertson et al., 2007). HIV-associated dementia bares certain similarities with that of Alzheimer disease (AD) (Clifford et al., 2009). The neurons of HIV-associated dementia patients contain diffuse $\mathrm{A} \beta$ plaques, similar to the early stages of $\mathrm{AD}$ (Ortega and Ances, 2014), which could indicate a slower progression of HIV-associated dementia (Fulop et al., 2019). 


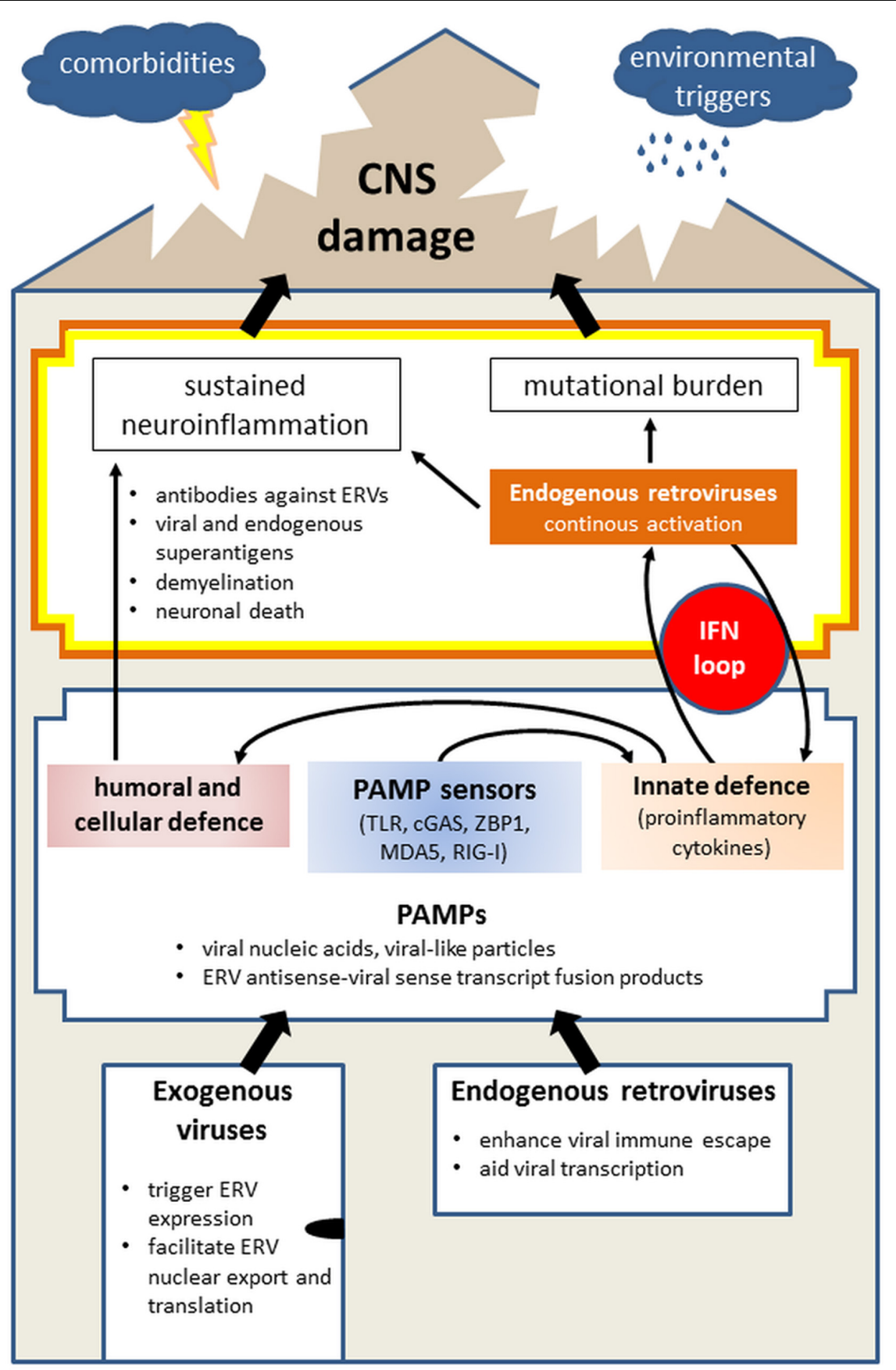

FIGURE 2 | Model of the role of exogenous virus and endogenous retrovirus (ERV) in initiating neuropathologies, illustrating the entry of viruses into the body ("house") and the presence of ERVs, the physiological immune response on the first level and continuous imbalance on the second, thus leading to damage of the CNS ("roof"). Infections with exogenous viruses often activate the transcription of endogenous retroviruses which are already present in the mammalian genome. This results from disruption of the host-control over ERVs, bordering between own and foreign. Separately and together, activated exogenous viruses and ERVs produce PAMPs, such as viral nucleic acids, viral-like particles, fused transcripts between exogenous virus, and ERV, which are sensed by PAMP sensors (TLR, cGAS, ZBP-1, MDA5, and RIG-I). Collectively, PAMP activation alarms the immune system by initiating innate immune response involving mainly IFN signaling which will trigger the adaptive (humoral and cellular) immunity. Viral infections are generally limited in time as they are combated by the immune system. However, the activation of ERVs and neurotrophic viruses which remain silent yet present within the body, can lead to sustained neuroinflammation via antibodies against ERVs, superantigen formation, demyelination, and neuronal death. In parallel, IFN-mediated innate immune response can further activate ERVs which contain IFN response elements (such as HERV-K), thereby creating an IFN loop. Next to the danger of chronic neuroinflammation, this additionally carries mutational burden for the host, collectively leading to the CNS damage. The probability and scope of the CNS damage is further determined by facilitating factors, including comorbidities and environmental triggers as well as age. Abbreviations: cGAS, cyclic GMP-AMP synthase; CNS, central nervous system; ERV, endogenous retrovirus; IFN, interferon; MDA5, melanoma differentiated associated gene 5; PAMP, pathogen-associated molecular pattern; RIG-I, retinoic acid inducible gene I; TLR, toll-like receptor; ZBP-1, Z-DNA binding protein 1. 
TABLE 1 | Overview of disorders affecting the central nervous system (CNS) associated with an onset mediated by exogenous viruses and/or endogenous retroviruses.

\begin{tabular}{|c|c|c|c|c|c|c|}
\hline Disorder & $\begin{array}{l}\text { Clinical CNS } \\
\text { symptoms }\end{array}$ & $\begin{array}{l}\text { Associated } \\
\text { peripheral } \\
\text { pathology }\end{array}$ & CNS targets & $\begin{array}{l}\text { Associated } \\
\text { exogenous } \\
\text { viruses }\end{array}$ & $\begin{array}{l}\text { Associated } \\
\text { endogenous } \\
\text { retroviruses }\end{array}$ & Mechanisms \\
\hline $\begin{array}{l}\text { HIV-associated } \\
\text { neurodegenerative } \\
\text { disorder (HAND) }\end{array}$ & $\begin{array}{l}\text { Cognitive, motor, } \\
\text { and behavioral } \\
\text { deficits similar to } \\
\text { AD }\end{array}$ & AIDS & $\begin{array}{l}\text { Microglia, } \\
\text { astrocytes, and } \\
\text { perivascular } \\
\text { macrophages, } \\
\text { neurons (motor } \\
\text { and cortical) }\end{array}$ & $\begin{array}{l}\text { HIV-1 } \\
\text { (aggravation by } \\
\text { CMV, EBV, } \\
\text { HHV-3, and } \\
\text { HHV-6) }\end{array}$ & $\begin{array}{l}\text { HERV-K } \\
\text { (HERV-E, HERV-T, two } \\
\text { ERV9 subgroups) }\end{array}$ & $\begin{array}{l}\text { - Neurotoxic viral products (Tat, Vpr, } \\
\text { HIV-1 gp120) } \\
\text { - Cytokine-induced HERV expression } \\
\text { (IL-6, IL-1 } \beta \text {, TNF- } \alpha \text {, IFN- } \gamma \text { ) } \\
\text { - Viral induction of antibody against } \\
\text { HERV-K capsid protein } \\
\text { - Sustained inflammation } \\
\text { - Increased pTau, neopterin, } \\
\text { neurofilament light and diffuse A } \beta \\
\text { plaques }\end{array}$ \\
\hline $\begin{array}{l}\text { Alzheimer's } \\
\text { disease (AD) }\end{array}$ & $\begin{array}{l}\text { Cognitive deficits } \\
\text { (memory loss, } \\
\text { learning difficulty, } \\
\text { impaired logical } \\
\text { thinking, confusion, } \\
\text { speech problems, } \\
\text { shortened attention } \\
\text { span) }\end{array}$ & $\begin{array}{l}\text { Systemic immune } \\
\text { activation, and } \\
\text { chronic peripheral } \\
\text { inflammation }\end{array}$ & $\begin{array}{l}\text { Microglia, } \\
\text { hippocampal } \\
\text { pyramidal neurons } \\
\text { lymphocytes, } \\
\text { neuronal, and } \\
\text { endothelial cells } \\
\text { parahippocampal, } \\
\text { inferior frontal and } \\
\text { superior temporal } \\
\text { gyrus }\end{array}$ & $\begin{array}{l}\text { HHV-1, } \\
\text { HHV-6A, } \\
\text { HHV-6B, } \\
\text { HHV-7, EBV, } \\
\text { and CMV }\end{array}$ & $\begin{array}{l}\text { HERV-K, HERV-H, } \\
\text { HERV-W, HERV-L, } \\
\text { solitary long-terminal } \\
\text { repeats (LTRs) }\end{array}$ & $\begin{array}{l}\text { - Extension of inflammation to CNS } \\
\text { (immune cells entry to brain via } \\
\text { transversal of circumventricular } \\
\text { organs, vagus nerve stimulation or } \\
\text { pro-inflammatory cytokine influx) } \\
\text { - Viral RNA sensor MAVS } \\
\text { - Gliosis } \\
\text { - Viral activation of HERVs } \\
\text { - Higher rate of DNA damage and } \\
\text { higher expression of } \\
\text { pluripotency-related genes } \\
\text { - HERV fusion products (ARC viral-like } \\
\text { capsid protein overexpression) } \\
\text { - HERV-induced TLR8 activation } \\
\text { - Progressive neuronal death } \\
\text { (PARP1-driven, caspase-independent } \\
\text { apoptosis) } \\
\text { - Dense A } \beta \text { plaques, Tau neurofibrillary } \\
\text { tangles }\end{array}$ \\
\hline $\begin{array}{l}\text { Multiple sclerosis } \\
\text { (MS) }\end{array}$ & $\begin{array}{l}\text { Progressive } \\
\text { physical and } \\
\text { cognitive } \\
\text { disabilities } \\
\text { neurobehavioural } \\
\text { deficits, such as } \\
\text { weakness, gait } \\
\text { unsteadiness, and } \\
\text { altered executive } \\
\text { functions }\end{array}$ & $\begin{array}{l}\text { Hints for chronic } \\
\text { inflammation, } \\
\text { association with } \\
\text { peripheral } \\
\text { neuropathy }\end{array}$ & $\begin{array}{l}\text { B cells, microglia, } \\
\text { astrocytes, and } \\
\text { macrophages that } \\
\text { orchestrate } \\
\text { damage to } \\
\text { oligodendrocytes }\end{array}$ & $\begin{array}{l}\text { HHV-1, HHV-2, } \\
\text { HHV-3, HHV-6, } \\
\text { EBV, CMV, JCV }\end{array}$ & $\begin{array}{l}\text { HERV-W (HERV-K, } \\
\text { HERV-H) }\end{array}$ & $\begin{array}{l}\text { - Viral activation of HERV-W } \\
\text { transcription } \\
\text { - HERV-W env protein and syncytin } \\
\text { expression } \\
\text { - HERV-W env is a powerful } \\
\text { superantigen } \\
\text { - Syncytin induces neuroinflammation } \\
\text { via oxidative stress } \\
\text { - Stimulate anti-viral response } \\
\text { associated with MS pathology by } \\
\text { binding TLR4 and CD14 } \\
\text { - Pro-inflammatory (anti-viral) response } \\
\text { involving TLR4, CD14, IL-1beta } \\
\text { - Increase in cellular protein oxidation, } \\
\text { inhibition of oligodendrocyte } \\
\text { maturation, myelin damage and } \\
\text { antagonization of remyelination }\end{array}$ \\
\hline $\begin{array}{l}\text { Amyotrophic lateral } \\
\text { sclerosis (ALS) }\end{array}$ & $\begin{array}{l}\text { Fasciculation, } \\
\text { cramps, muscle } \\
\text { atrophy, and } \\
\text { marked limb } \\
\text { weakness }\end{array}$ & $\begin{array}{l}\text { HERV-W env and } \\
\text { gag are present in } \\
\text { muscle biopsies } \\
\text { from ALS patients, } \\
\text { linked with } \\
\text { macrophage } \\
\text { activation and } \\
\text { neurogenic atrophy } \\
\text { of muscular tissue }\end{array}$ & $\begin{array}{l}\text { HERV activity in } \\
\text { prefrontal, sensory, } \\
\text { motor, occipital } \\
\text { cortex }\end{array}$ & $\begin{array}{l}\text { Weak } \\
\text { connection } \\
\text { with HIV-1, and } \\
\text { HTLV-1 }\end{array}$ & HERV-K & $\begin{array}{l}\text { - HERV-K transcription in ALS is } \\
\text { stimulated by the TDP-43 } \\
\text { - HERV-K transcription can be also } \\
\text { initiated by HIV-Tat protein HERV-K } \\
\text { env in cortical and spinal neurons } \\
\text { - neuronal HERV-K activation is } \\
\text { associated with the nuclear } \\
\text { translocation of interferon regulatory } \\
\text { factor } 1 \text { (IRF1) } \\
\text { - Sustained neuroinflammation with } \\
\text { progressive loss of cortical and spinal } \\
\text { motor neurons }\end{array}$ \\
\hline $\begin{array}{l}\text { Schizophrenia } \\
\text { spectrum disorders }\end{array}$ & $\begin{array}{l}\text { Psychosis, } \\
\text { hallucinations, } \\
\text { delusions, apathy } \\
\text { and disorganized } \\
\text { thinking }\end{array}$ & $\begin{array}{l}\text { Subclinical } \\
\text { inflammation }\end{array}$ & $\begin{array}{l}\text { Neurons of } \\
\text { prefrontal cortex } \\
\text { and (developing) } \\
\text { hippocampus }\end{array}$ & $\begin{array}{l}\text { HHV-2, } \\
\text { perinatal } \\
\text { influenza } \\
\text { infection }\end{array}$ & $\begin{array}{l}\text { HERV-W, LINE-1 } \\
\text { (HERV-K, HERV-H) }\end{array}$ & $\begin{array}{l}\text { - Impairment of synaptic genes } \\
\text { - Upregulation of immune response } \\
\text { genes } \\
\text { - Lasting inflammatory dysregulation of } \\
\text { the nervous system }\end{array}$ \\
\hline
\end{tabular}


TABLE 1 | Continued

\begin{tabular}{|c|c|c|c|c|c|c|}
\hline Disorder & $\begin{array}{l}\text { Clinical CNS } \\
\text { symptoms }\end{array}$ & $\begin{array}{l}\text { Associated } \\
\text { peripheral } \\
\text { pathology }\end{array}$ & CNS targets & $\begin{array}{l}\text { Associated } \\
\text { exogenous } \\
\text { viruses }\end{array}$ & $\begin{array}{l}\text { Associated } \\
\text { endogenous } \\
\text { retroviruses }\end{array}$ & Mechanisms \\
\hline $\begin{array}{l}\text { Neuropathogenesis } \\
\text { of SARS-CoV-2 }\end{array}$ & $\begin{array}{l}\text { Dizziness, } \\
\text { headache, } \\
\text { encephalitis, } \\
\text { seizures, } \\
\text { intracerebral } \\
\text { hemorrhage, and } \\
\text { stroke, } \\
\text { neuromuscular and } \\
\text { autoimmune } \\
\text { syndromes }\end{array}$ & $\begin{array}{l}\text { Acute respiratory } \\
\text { disease }\end{array}$ & $\begin{array}{l}\text { Viral infection of } \\
\text { neurons and glial } \\
\text { cells }\end{array}$ & SARS-CoV-2 & none & $\begin{array}{l}\text { - Interacts with stress response, vesicle } \\
\text { trafficking, lipid metabolism pathways, } \\
\text { production of reactive oxygen species, } \\
\text { RNA processing, RNA regulation, } \\
\text { ubiquitin ligases and mitochondrial } \\
\text { activity } \\
\text { - Impaired lysosomal function } \\
\text { combined with inhibition of } \\
\text { ubiquitin-proteasome system } \\
\text { - Protein misfolding and formation of } \\
\text { protein aggregates } \\
\text { - Expected neuroinflammation and } \\
\text { neurodegeneration }\end{array}$ \\
\hline
\end{tabular}

A 3 , amyloid $\beta$; AD, Alzheimer's disease; AIDS, acquired immunodeficiency syndrome; ALS, amyotrophic lateral sclerosis; CD14, cluster of differentiation 14; CMV, cytomegalovirus; EBV, Epstein-Barr virus; gp120, glycoprotein 120; HAND, HIV-associated neurodegenerative disorder; HERV, human endogenous retrovirus; HHV-1, human alphaherpesvirus-1/herpes simplex virus-1; HHV-2, human alphaherpesvirus-2/herpes simplex virus-2; HHV-3, human alphaherpesvirus-3/varicella zoster virus; HHV-6, human alphaherpesvirus-6; HHV-7, human alphaherpesvirus-7; HIV-1, human immunodeficiency virus-1; HTLV-1, human T-cell leukemia virus-1; IFN- $\gamma$, interferon $\gamma$; IL, interleukin; IRF1, interferon regulatory factor 1; JCV, John Cunningham virus; LINE-1, long interspersed repetitive element 1; LTR, long-terminal repeat; MAVS, mitochondrial antiviral-signaling protein; MS, multiple sclerosis; SARS-CoV-2, severe acute respiratory syndrome coronavirus-2; Tat transactivator of transcription; TDP-43, trans-activation responsive TAR; DNA-binding protein 43; TLR, toll-like receptor; TNF- $\alpha$, tumor necrosis factor $\alpha$; Vpr, viral protein $R$.

\section{Alzheimer's Disease}

Alzheimer's disease $(\mathrm{AD})$ is a progressive neurodegenerative disorder characterized by gradual cognitive decline. AD can start even decades before the appearance of clinical symptoms (Taylor et al., 2016; Fulop et al., 2018). AD is associated with systemic immune activation and chronic peripheral inflammation (Culibrk and Hahn, 2020). Neuropathologically, AD is characterized by presence of $A \beta$ plaques, Tau neurofibrillary tangles, progressive neuronal death, neuroinflammation, and gliosis in the brain.

Growing evidence points to the role of pathogens, such as HHV-1, HHV-6A, HHV-7 (Lovheim et al., 2015; Readhead et al., 2018), EBV, and CMV (Carbone et al., 2014) in developing sporadic $\mathrm{AD}$. As the worldwide seroprevalence of HHV-1 is around 90\% (Wald and Corey, 2007), facilitating factors essentially contribute to the probability of $\mathrm{HHV}-1$ triggering AD (Looker et al., 2015). HHV-1, HHV-6A, and HHV-6B viral glycoproteins can bind $\beta$-amyloid oligomers and accelerate $A \beta$ plaque deposition (Eimer et al., 2018).

HERV-H, HERV-K, HERV-L, and HERV-W are transcriptionally active in the brains of $\mathrm{AD}$ patients (Johnston et al., 2001; Sun et al., 2018; Dembny et al., 2020). This activation could be directly mediated by HHV-1, HHV-3, and HHV-6 (Ruprecht et al., 2006; Brudek et al., 2007; Tai et al., 2009), or by heterochromatin relaxation and loss of epigenetic host control over HERVs (Sun et al., 2018), increasing DNA damage and expression of pluripotency-related genes (Frost et al., 2014). Upregulation of ERV-K family member in a streptozotocin murine model of sporadic AD was linked with upregulation of immune response genes and downregulation of genes involved in histone modifications and transmembrane transport and associated with cognitive impairments in contextual fear memory and spatial learning (Sankowski et al., 2019). HERV-K (HML-2) transcripts containing a motif 5'-GUUGUGU-3' contribute to neuronal death and microglial accumulation associated with AD via TLR8 activation (Dembny et al., 2020). ERVs can be transmitted between neurons in the brains of $\mathrm{AD}$ patients, packed into an ARC viral-like capsid protein, which is overexpressed in $\mathrm{AD}$ patients and is associated with $\mathrm{A} \beta$ production (Wu et al., 2011).

\section{Multiple Sclerosis}

Multiple sclerosis (MS) is a neurodegenerative and neuroinflammatory CNS disease characterized by multifocal demyelinating lesions in the brain and spinal cord leading to progressive physical and cognitive disabilities. Development of MS has been associated with viral infections and activation of HERVs (Alvarez-Lafuente et al., 2008; Kriesel et al., 2017; Morandi et al., 2017; Gruchot et al., 2020).

Among viruses, higher transcription levels of HHV-3 and HHV-6 have been found in the CSF of individuals suffering from MS (Mancuso et al., 2007; Alvarez-Lafuente et al., 2008). Also, coronaviruses have been detected in the CNS of MS patients (Burks et al., 1980). EBV has been even suggested as a trigger for MS that activates HERV-W, which then sustains the disease (Mameli et al., 2012).

HERV-W is also the main HERV associated with MS pathology. Further, the expression level of HERV-W in the brain of MS patients correlates positively with the severity of disability and disease progression (Sotgiu et al., 2010). HERV-W and its env transcript and protein are upregulated in the brains (Perron et al., 1997; Antony et al., 2004) as well as in the peripheral blood and serum of MS patients (Garson et al., 1998; Perron et al., 2012a). HERV-W can be activated in MS by EBV (Mameli et al., 2012) and HHV-1 (Ruprecht et al., 2006; Marrodan et al., 2019). HHV-1-triggered HERV-W transcription occurs in immune cells central to the MS pathology, such as B cells, microglia, astrocytes, and macrophages (Ruprecht et al., 2006; Marrodan et al., 2019). 
HERV-W env protein activates dendritic cells and boosts T helper lymphocyte type-1 (Th1) immune response, acting as a PAMP. It stimulates pro-inflammatory anti-viral response by binding TLR4 and CD14 (Rolland et al., 2006; Saresella et al., 2009). Upon binding the TLR4 on oligodendroglial precursor cells, HERV-W env stimulates release of pro-inflammatory cytokines, inducible nitric oxide synthase, and formation of nitrotyrosine groups leading to reduction of myelin expression in MS lesions (Kremer et al., 2013). In addition to the above, HERV-W env is a powerful superantigen linked with demyelination in MS (Perron et al., 2001; Rolland et al., 2005), perhaps associated with molecular mimicry with myelin oligodendrocyte glycoprotein (MOG) (do Olival et al., 2013; de Luca et al., 2019). Accordingly, treatment with HERV-W env antibody can effectively rescue myelin expression (Kremer et al., 2015).

Mechanistically, HERV-W env protein has been shown to induce microglial polarization and closely associate with myelinated axons in MS lesions ultimately leading to structural damage of these axons (Kremer et al., 2019). HERV-W env, encoded from a full-length provirus at locus 7q21.2, gives rise to a syncytin glycoprotein (Blond et al., 2000; Mi et al., 2000), the expression of which, similar to HERV-W env, is increased by threefold in the brain tissue of MS patients compared with the controls (Antony et al., 2004; van Horssen et al., 2016). HERV-W env and syncytin expression is confined to immunologically active cells, including cells resembling activated glia and phagocytic macrophages at acute and chronic MS demyelinating lesions (Antony et al., 2004; van Horssen et al., 2016). Syncytin activation leads to a myriad of MS-associated pathology, such as pro-inflammatory profile in astrocytes, interleukin-1 $\beta$ (IL-1 $\beta$ ) production, cellular protein oxidation, inhibition of oligodendrocyte maturation, myelin damage, and antagonization of remyelination up to neurobehavioral deficits (Antony et al., 2004).

The central role of HERV-W env in MS neurodegeneration has led to the development of a specific monoclonal antibody, Temelimab (GNbAC1) (Curtin et al., 2012), an agent currently being tested in clinical phase II (ClinicalTrials.gov identifier: NCT02782858).

\section{Amyotrophic Lateral Sclerosis}

Amyotrophic lateral sclerosis (ALS) is a neurodegenerative disease, characterized by progressive loss of cortical and spinal motor neurons. While majority of ALS cases are sporadic, mutations in certain genes, such as trans-activation responsive (TAR) DNA-binding protein 43 (TDP-43), have been associated with ALS development (Yousefian-Jazi et al., 2020).

That ALS might be linked with viral infections, comes from finding HIV and HTLV-1 presence in the brains of ALS patients (Verma and Berger, 2006). Further, antiretroviral therapy of HIV-infected individuals with ALS-like syndrome reverses the symptoms related to ALS (Moulignier et al., 2001). The CSF of ALS patients negative of HIV, contains viral reverse transcriptase at levels seen in HIV-infected individuals (MacGowan et al., 2007; McCormick et al., 2008). This has led to investigation of HERVs and revealed the central role of HERV-K among the HERVs in ALS pathogenesis. HERV-K pol, gag, and env are all transcriptionally active in the prefrontal, sensory, motor, and occipital cortex of ALS patients (Douville et al., 2011; Li et al., 2015) and HERV-K env additionally in spinal neurons of sporadic ALS patients. Higher serum IgG and IgM reactivity toward HERV-K gag is also characteristic to ALS patients ( $\mathrm{Li}$ et al., 2015). HERV-K in ALS can be activated by several mechanisms and occur from distinct cytogenic loci (at 7q36.1) (Douville et al., 2011). These mechanisms include neuronal injury and neuroinflammation through interferon-stimulated response elements in the viral promoter (Gonzalez-Hernandez et al., 2014; Manghera et al., 2016). Once activated, neuronal HERV$\mathrm{K}$ upregulation contributes to sustained neuroinflammation through promoting nuclear translocation of IFN regulatory factor 1 (IRF1) and NF- $\kappa$ B isoforms p50 and p65 (Manghera et al., 2016). Also, TDP-43 activates HERV-K upon binding its DNA (Li et al., 2015). HERV-K and TDP-43 expression in ALS are strongly correlated (Douville et al., 2011). HERV-K env expression leads to neurite retraction, beading, and neurodegeneration (Chen et al., 2014; Li et al., 2015).

\section{Schizophrenia Spectrum Disorders}

Schizophrenia is a neuropsychiatric and neurodevelopmental disorder characterized by episodes of psychosis, hallucinations, and delusions. Disease typically starts in young adulthood and is strongly affected by genetic background and environmental factors (Owen et al., 2016). The neurobiology behind schizophrenia is poorly understood.

The likelihood of developing schizophrenia is increased by infections (most significantly evidenced with studies on HHV2) (Arias et al., 2012), subclinical inflammation (Frydecka et al., 2018), and variation within brain-associated and immune genes (Schizophrenia Working Group of the Psychiatric Genomics, 2014). Altered immune response and lasting inflammatory dysregulation of the nervous system are associated with chronic stress exposure (Pearce et al., 2019; Nettis et al., 2020). Upregulated immune response genes induce hyperactivation of LINE-1, which is common in schizophrenia patients (Bundo et al., 2014). Increased retrotransposition of LINE-1 is found in the neurons of prefrontal cortex, affecting intragenic regions and synaptic genes (Bundo et al., 2014).

In addition to LINE-1, expression of several HERV families, such as HERV-K, HERV-W, and HERV-H, has been shown to be dysregulated in the brains, cerebrospinal fluid, and blood of schizophrenia patients (Perron et al., 2012b; Li et al., 2019; Mak et al., 2019). This could involve activation of distinct HERV loci. For example, activated HERV-W env transcripts in schizophrenia have been shown to differ from these activated in bipolar disorder or MS. Combined with HERV-W copy number differences between schizophrenia patients and healthy controls, this might point to perinatal HERV-W activation (for instance by infections such as influenza), potentially leading to inflammation and subsequent neurotoxicity (Limosin et al., 2003; Perron et al., 2008, 2012b). HERV-W env protein expression in developing hippocampus was recently shown to alter the N-methyl-daspartate receptor (NMDAR)-mediated synaptic organization and plasticity. This was associated with defective glutamate synapse maturation, behavioral impairments, and psychosis 
(Johansson et al., 2020). Apart from HERV-W, lower DNA methylation levels at HERV-K sequences in peripheral blood have been shown to be specific to early stages of schizophrenia (Mak et al., 2019).

\section{Neuropathogenesis of SARS-CoV-2}

Highly pathogenic severe acute respiratory syndrome coronavirus-2 (SARS-CoV-2) is a single-stranded RNA virus from the coronavirus's family (Su et al., 2016).

SARS-CoV-2 enters host via its immunogenic spike glycoprotein binding to ACE2 receptor on endothelial and smooth muscle cells (Lan et al., 2020; Kaneko et al., 2021). Resultant coronavirus disease 2019 (COVID-19) mainly presents as an acute respiratory disease; however, also neurological symptoms have been reported, including dizziness, headache, encephalitis, seizures, intracerebral hemorrhage, and stroke (Benger et al., 2020; Guadarrama-Ortiz et al., 2020; Huang et al., 2020; Lu et al., 2020; Moriguchi et al., 2020). In addition, neuromuscular and autoimmune complications are associated with COVID-19. These include most frequently Guillain Barré syndrome but also Miller Fisher syndrome, polyneuritis cranialis, acute myelitis, oculomotor paralysis, and Bell's palsy have been reported (Guadarrama-Ortiz et al., 2020; Katyal et al., 2020). SARS-CoV-2 uses the olfactory nerves and possibly the vagus nerve to access the brain (Guadarrama-Ortiz et al., 2020; Liu et al., 2020) where ACE2 receptor is expressed on neurons and glial cells (Zou et al., 2020). The neuromuscular invasion of SARS-CoV-2 likely involves retrograde axonal transfer of the virus in trans-synaptic pathway and cytokine storm (Katyal et al., 2020).

SARS-CoV-2 viral proteins interact with human proteins that regulate cellular longevity and aging, and are involved in stress response, vesicle trafficking, lipid metabolism, production of reactive oxygen species, RNA regulation, ubiquitin ligases, and mitochondrial activity (Gordon et al., 2020). Impaired lysosomal function combined with inhibition of ubiquitin-proteasome system can cause protein misfolding and protein aggregation in affected cells, including neurons, a common mechanism of many neurodegenerative diseases (Lippi et al., 2020).

Up to one third of COVID-19 patients develop neurological symptoms beyond the acute stage of the disease, mainly manifesting with chronic fatigue syndrome and myalgic encephalomyelitis (Nath and Smith, 2021). That several coronaviruses (CoV-OC-43, CoV-229E, and $\mathrm{HCoV}$ ) are found in the brains of MS patients or have been associated with MS pathology (Burks et al., 1980; Murray et al., 1992) could indicate MS-like demyelinating neuropathology as a possible long-term complication of COVID-19. Further, it remains to be investigated how SARS-CoV-2 affects the expression of HERVs, LINE-1, and Alu elements and interacts with other viruses and environmental factors.

\section{AGING}

Aging is a progressive deterioration of physiological functions at the cellular, organ, and organism levels eventually leading to senescence. Aging disrupts the balance between the nervous and the immune system and increases risk for various neurodegenerative and neuroinflammatory diseases (Streit et al., 2004; Godbout et al., 2005; Valdes-Ferre et al., 2020).

Aging increases genomic instability (Lombard et al., 2005) by gradual loss of global DNA methylation and region-specific DNA hypermethylation (Jung and Pfeifer, 2015). Increased agerelated activation of certain retrotransposon families is found in mice (ERVs) (Odaka, 1975) and Drosophila (LINE-like R2, LTR element gypsy transcripts, and env glycoprotein) (Li et al., 2013). In humans, aging causes profound de-repression of HERV-K, Alu, and LINE-1 elements (Bollati et al., 2009; Cardelli, 2018) with increasing chromatin openness at Alu, SVA, and LINE1 elements in senescent cells (De Cecco et al., 2013). This affects most significantly evolutionarily younger elements (De Cecco et al., 2013). Transcription levels of HERV-H, HERV$\mathrm{K}$, and HERV-W change in distinct patterns during human life. HERV-H is highly transcribed in childhood, while HERV$\mathrm{K}$ and also HERV-W transcription increases on reaching higher age (Balestrieri et al., 2015; Autio et al., 2020). ERV activation in aging Drosophila causes shorter lifespan, neurodegeneration, and memory deficits (Li et al., 2013). Similar effects of ERV activation on hippocampal memory and cognitive impairment are observed in mice (Sankowski et al., 2019). Particularly, in combination with chronic inflammation, the effect of HERV activation in aging brain can be detrimental and contribute to neuronal decline (Johnston et al., 2001; Sankowski et al., 2019). In addition to HERVs, LINE-1 hypomethylation has been described in the peripheral blood of elderly individuals (Mahmood et al., 2020). Some of the age-related epigenetic changes, such as those related to Alu methylation, seem to be regulated by longevity-associated genetic factors, including genes involved in nucleotide biosynthesis, metabolism, and signal transduction (Gentilini et al., 2013).

Aging can determine the outcome of interplay between endogenous and exogenous viruses. Interaction of the endogenous murine leukemia virus with the generally non-pathogenic murine togavirus lactate dehydrogenaseelevating virus leads to a fatal and progressive neurological disease in up to $100 \%$ of aged mice. This suggests convergence of age-related, genetic, immunological, and viral factors in the development of a neurological disease resembling ALS in humans (Contag and Plagemann, 1989).

\section{CONCLUDING REMARKS}

This review brings together studies that have described a role for exogenous viruses and (H)ERVs in CNS pathologies and thereby highlights the interplay between the inherent and the foreign. A contribution of exogenous and endogenous viruses, separately and together, is increasingly evident in common forms of dementia in young (HAND) and elderly population (AD), MS, ALS, and also schizophrenia. In other neurological complications of viral origin, such as SARS-CoV-2, it remains to be seen if and how HERV, LINE-1, and Alu expression may be involved. Viral CNS infections can be early triggers 
of neuroinflammation; however, if viruses are successfully combated or entered in a latent state, a central role might be attributed to endogenous retroviruses. ERV activation during infections seems to be a common (physiological) mechanism that the host may not be able to control at some point. ERVs can become continuously activated and sustain the inflammatory imbalance. The crosstalk with IFN seems to play an important role here. Facilitating factors that are associated with continuous ERV activation such as aging, stress, and other comorbidities as well as reawakening of a latent virus, cumulative or opportunistic infections, as seen in immune-deprived conditions, contribute to the progressive neurodegeneration or delayed CNS pathologies. We are only beginning to understand how exogenous viruses in connection with HERVs and other retroelements affect normal aging and development of neurodegenerative diseases and other neuropathologies. The central role of HERV-W in MS pathology has led to its targeting in clinical trials. It remains to be seen, whether other HERVs could provide key targets in other neurodegenerative

\section{REFERENCES}

Acha-Orbea, H. (1992). Retroviral superantigens. Chem. Immunol. 55, 65-86. doi: 10.1159/000319131

Albright, A. V., Shieh, J. T., O'Connor, M. J., and Gonzalez-Scarano, F. (2000). Characterization of cultured microglia that can be infected by HIV-1. J. Neurovirol. 6, S53-S60.

Almeida, O. P., and Lautenschlager, N. T. (2005). Dementia associated with infectious diseases. Int. Psychogeriatr. 17, S65-S77.

Alvarez-Lafuente, R., Garcia-Montojo, M., De Las Heras, V., Dominguez-Mozo, M. I., Bartolome, M., Benito-Martin, M. S., et al. (2008). Herpesviruses and human endogenous retroviral sequences in the cerebrospinal fluid of multiple sclerosis patients. Mult. Scler 14, 595-601. doi: 10.1177/1352458507086425

Antony, J. M., van Marle, G., Opii, W., Butterfield, D. A., Mallet, F., Yong, V. W., et al. (2004). Human endogenous retrovirus glycoprotein-mediated induction of redox reactants causes oligodendrocyte death and demyelination. Nat. Neurosci. 7, 1088-1095. doi: 10.1038/nn1319

Arias, I., Sorlozano, A., Villegas, E., de Dios Luna, J., McKenney, K., Cervilla, J., et al. (2012). Infectious agents associated with schizophrenia: a meta-analysis. Schizophr. Res. 136, 128-136. doi: 10.1016/j.schres.2011. 10.026

Autio, A., Nevalainen, T., Mishra, B. H., Jylha, M., Flinck, H., and Hurme, M. (2020). Effect of aging on the transcriptomic changes associated with the expression of the HERV-K (HML-2) provirus at 1q22. Immun. Ageing 17:11.

Bachiller, S., Del-Pozo-Martin, Y., and Carrion, A. M. (2017). L1 retrotransposition alters the hippocampal genomic landscape enabling memory formation. Brain Behav. Immun. 64, 65-70. doi: 10.1016/j.bbi.2016.12.018

Baillie, J. K., Barnett, M. W., Upton, K. R., Gerhardt, D. J., Richmond, T. A., De Sapio, F., et al. (2011). Somatic retrotransposition alters the genetic landscape of the human brain. Nature 479, 534-537. doi: 10.1038/nature10531

Balestrieri, E., Matteucci, C., Cipriani, C., Grelli, S., Ricceri, L., Calamandrei, G., et al. (2019). Endogenous Retroviruses Activity as a Molecular Signature of Neurodevelopmental Disorders. Int. J. Mol. Sci. 20:6050. doi: 10.3390/ ijms 20236050

Balestrieri, E., Pica, F., Matteucci, C., Zenobi, R., Sorrentino, R., Argaw-Denboba, A., et al. (2015). Transcriptional activity of human endogenous retroviruses in human peripheral blood mononuclear cells. Biomed. Res. Int. 2015:164529.

Bannert, N., and Kurth, R. (2004). Retroelements and the human genome: new perspectives on an old relation. Proc. Natl. Acad. Sci. U. S. A. 101, 14572-14579. doi: 10.1073/pnas.0404838101

Bedrosian, T. A., Linker, S., and Gage, F. H. (2016). Environment-driven somatic mosaicism in brain disorders. Genome Med. 8:58. diseases, such as HERV-K in ALS, to which there is currently no cure.

\section{AUTHOR CONTRIBUTIONS}

CR designed the manuscript idea, performed literature search, and wrote the manuscript.

\section{FUNDING}

This publication was funded by the publication fund of the Max Delbrück Center for Molecular Medicine in the Helmholtz Association, Berlin, Germany.

\section{ACKNOWLEDGMENTS}

CR would like to thank Dr. Lutz Römer for critical reading of the manuscript.

Benger, M., Williams, O., Siddiqui, J., and Sztriha, L. (2020). Intracerebral haemorrhage and COVID-19: Clinical characteristics from a case series. Brain Behav. Immun. 88, 940-944. doi: 10.1016/j.bbi.2020.06.005

Bertrand, L., Meroth, F., Tournebize, M., Leda, A. R., Sun, E., and Toborek, M. (2019). Targeting the HIV-infected brain to improve ischemic stroke outcome. Nat. Commun. 10:2009.

Bhardwaj, N., Maldarelli, F., Mellors, J., and Coffin, J. M. (2014). HIV-1 infection leads to increased transcription of human endogenous retrovirus HERV-K (HML-2) proviruses in vivo but not to increased virion production. J. Virol. 88, 11108-11120. doi: 10.1128/jvi.01623-14

Bhat, R. K., Rudnick, W., Antony, J. M., Maingat, F., Ellestad, K. K., Wheatley, B. M., et al. (2014). Human endogenous retrovirus-K(II) envelope induction protects neurons during HIV/AIDS. PLoS One 9:e97984. doi: 10.1371/journal. pone.0097984

Blond, J. L., Lavillette, D., Cheynet, V., Bouton, O., Oriol, G., Chapel-Fernandes, S., et al. (2000). An envelope glycoprotein of the human endogenous retrovirus HERV-W is expressed in the human placenta and fuses cells expressing the type D mammalian retrovirus receptor. J. Virol. 74, 3321-3329. doi: 10.1128/jvi.74. 7.3321-3329.2000

Bodea, G. O., McKelvey, E. G. Z., and Faulkner, G. J. (2018). Retrotransposoninduced mosaicism in the neural genome. Open Biol. 8:180074. doi: 10.1098/ rsob. 180074

Bollati, V., Schwartz, J., Wright, R., Litonjua, A., Tarantini, L., Suh, H., et al. (2009). Decline in genomic DNA methylation through aging in a cohort of elderly subjects. Mech. Ageing Dev. 130, 234-239. doi: 10.1016/j.mad.2008.12. 003

Bostanciklioglu, M. (2020). SARS-CoV2 entry and spread in the lymphatic drainage system of the brain. Brain Behav. Immun. 87, 122-123. doi: 10.1016/j. bbi.2020.04.080

Bowen, L. N., Tyagi, R., Li, W., Alfahad, T., Smith, B., Wright, M., et al. (2016). HIV-associated motor neuron disease: HERV-K activation and response to antiretroviral therapy. Neurology 87, 1756-1762. doi: 10.1212/wnl. 0000000000003258

Brudek, T., Luhdorf, P., Christensen, T., Hansen, H. J., and Moller-Larsen, A. (2007). Activation of endogenous retrovirus reverse transcriptase in multiple sclerosis patient lymphocytes by inactivated HSV-1. HHV-6 and VZV. J. Neuroimmunol. 187, 147-155. doi: 10.1016/j.jneuroim.2007.04.003

Brutting, C., Narasimhan, H., Hoffmann, F., Kornhuber, M. E., Staege, M. S., and Emmer, A. (2018). Investigation of Endogenous Retrovirus Sequences in the Neighborhood of Genes Up-regulated in a Neuroblastoma Model after Treatment with Hypoxia-Mimetic Cobalt Chloride. Front. Microbiol. 9:287. doi: $10.3389 /$ fmicb.2018.00287 
Bundo, M., Toyoshima, M., Okada, Y., Akamatsu, W., Ueda, J., Nemoto-Miyauchi, T., et al. (2014). Increased 11 retrotransposition in the neuronal genome in schizophrenia. Neuron 81, 306-313. doi: 10.1016/j.neuron.2013.10.053

Burks, J. S., DeVald, B. L., Jankovsky, L. D., and Gerdes, J. C. (1980). Two coronaviruses isolated from central nervous system tissue of two multiple sclerosis patients. Science 209, 933-934. doi: 10.1126/science.7403860

Carbone, I., Lazzarotto, T., Ianni, M., Porcellini, E., Forti, P., Masliah, E., et al. (2014). Herpes virus in Alzheimer's disease: relation to progression of the disease. Neurobiol. Aging 35, 122-129.

Cardelli, M. (2018). The epigenetic alterations of endogenous retroelements in aging. Mech. Ageing Dev. 174, 30-46. doi: 10.1016/j.mad.2018.02.002

Chai, Q., He, W. Q., Zhou, M., Lu, H., and Fu, Z. F. (2014). Enhancement of bloodbrain barrier permeability and reduction of tight junction protein expression are modulated by chemokines/cytokines induced by rabies virus infection. J. Virol. 88, 4698-4710. doi: 10.1128/jvi.03149-13

Chen, H., Qian, K., Du, Z., Cao, J., Petersen, A., Liu, H., et al. (2014). Modeling ALS with iPSCs reveals that mutant SOD1 misregulates neurofilament balance in motor neurons. Cell Stem Cell 14, 796-809. doi: 10.1016/j.stem.2014.02.004

Chuong, E. B., Elde, N. C., and Feschotte, C. (2016). Regulatory evolution of innate immunity through co-option of endogenous retroviruses. Science 351, 1083-1087. doi: 10.1126/science.aad5497

Chuong, E. B., Elde, N. C., and Feschotte, C. (2017). Regulatory activities of transposable elements: from conflicts to benefits. Nat. Rev. Genet. 18, 71-86. doi: 10.1038/nrg.2016.139

Clifford, D. B., Fagan, A. M., Holtzman, D. M., Morris, J. C., Teshome, M., Shah, A. R., et al. (2009). CSF biomarkers of Alzheimer disease in HIVassociated neurologic disease. Neurology 73, 1982-1987. doi: 10.1212/wnl. 0b013e3181c5b445

Contag, C. H., and Plagemann, P. G. (1989). Age-dependent poliomyelitis of mice: expression of endogenous retrovirus correlates with cytocidal replication of lactate dehydrogenase-elevating virus in motor neurons. J. Virol. 63, 4362-4369. doi: 10.1128/jvi.63.10.4362-4369.1989

Contreras-Galindo, R., Almodovar-Camacho, S., Gonzalez-Ramirez, S., Lorenzo, E., and Yamamura, Y. (2007). Comparative longitudinal studies of HERV-K and HIV-1 RNA titers in HIV-1-infected patients receiving successful versus unsuccessful highly active antiretroviral therapy. AIDS Res. Hum. Retrovir. 23, 1083-1086. doi: 10.1089/aid.2007.0054

Coufal, N. G., Garcia-Perez, J. L., Peng, G. E., Yeo, G. W., Mu, Y., Lovci, M. T., et al. (2009). L1 retrotransposition in human neural progenitor cells. Nature 460, 1127-1131. doi: 10.1038/nature08248

Culibrk, R. A., and Hahn, M. S. (2020). The Role of Chronic Inflammatory Bone and Joint Disorders in the Pathogenesis and Progression of Alzheimer's Disease. Front. Aging Neurosci. 12:583884. doi: 10.3389/fnagi.2020.583884

Curtin, F., Lang, A. B., Perron, H., Laumonier, M., Vidal, V., Porchet, H. C., et al. (2012). GNbAC1, a humanized monoclonal antibody against the envelope protein of multiple sclerosis-associated endogenous retrovirus: a first-inhumans randomized clinical study. Clin. Ther. 34, 2268-2278. doi: 10.1016/ j.clinthera.2012.11.006

Dando, S. J., Mackay-Sim, A., Norton, R., Currie, B. J., St John, J. A., Ekberg, J. A., et al. (2014). Pathogens penetrating the central nervous system: infection pathways and the cellular and molecular mechanisms of invasion. Clin. Microbiol. Rev. 27, 691-726. doi: 10.1128/cmr.00118-13

De Cecco, M., Criscione, S. W., Peckham, E. J., Hillenmeyer, S., Hamm, E. A., Manivannan, J., et al. (2013). Genomes of replicatively senescent cells undergo global epigenetic changes leading to gene silencing and activation of transposable elements. Aging Cell 12, 247-256. doi: 10.1111/acel.1 2047

de Luca, V., Martins Higa, A., Malta Romano, C., Pimenta Mambrini, G., Peroni, L. A., Trivinho-Strixino, F., et al. (2019). Cross-reactivity between myelin oligodendrocyte glycoprotein and human endogenous retrovirus $\mathrm{W}$ protein: nanotechnological evidence for the potential trigger of multiple sclerosis. Micron 120, 66-73. doi: 10.1016/j.micron.2019.02.005

de Mulder, M., SenGupta, D., Deeks, S. G., Martin, J. N., Pilcher, C. D., Hecht, F. M., et al. (2017). Anti-HERV-K (HML-2) capsid antibody responses in HIV elite controllers. Retrovirology 14:41.

Del Re, B., and Giorgi, G. (2020). Long INterspersed element-1 mobility as a sensor of environmental stresses. Environ. Mol. Mutagen 61, 465-493. doi: $10.1002 / \mathrm{em} .22366$
Dembny, P., Newman, A. G., Singh, M., Hinz, M., Szczepek, M., Kruger, C., et al. (2020). Human endogenous retrovirus HERV-K(HML-2) RNA causes neurodegeneration through Toll-like receptors. JCI Insight 5:e131093.

Deroux, A., Larrat, S., Hilleret, M. N., Baccard, M., Qin, W., Billet, G., et al. (2012). Case report: detection of a hepatitis B surface antigen variant emerging in an elderly patient after an ischemic cerebral vascular accident. J. Med. Virol. 84, 1897-1900. doi: 10.1002/jmv.23420

Dewannieux, M., Esnault, C., and Heidmann, T. (2003). LINE-mediated retrotransposition of marked Alu sequences. Nat. Genet. 35, 41-48. doi: 10. $1038 /$ ng1223

Diem, O., Schaffner, M., Seifarth, W., and Leib-Mosch, C. (2012). Influence of antipsychotic drugs on human endogenous retrovirus (HERV) transcription in brain cells. PLoS One 7:e30054. doi: 10.1371/journal.pone.0030054

Dixon, J. R., Selvaraj, S., Yue, F., Kim, A., Li, Y., Shen, Y., et al. (2012). Topological domains in mammalian genomes identified by analysis of chromatin interactions. Nature 485, 376-380. doi: 10.1038/nature11082

do Olival, G. S., Faria, T. S., Nali, L. H., de Oliveira, A. C., Casseb, J., Vidal, J. E., et al. (2013). Genomic analysis of ERVWE2 locus in patients with multiple sclerosis: absence of genetic association but potential role of human endogenous retrovirus type $\mathrm{W}$ elements in molecular mimicry with myelin antigen. Front. Microbiol. 4:172. doi: 10.3389/fmicb.2013.00345

Douville, R. N., and Nath, A. (2017). Human Endogenous Retrovirus-K and TDP43 Expression Bridges ALS and HIV Neuropathology. Front. Microbiol. 8:1986. doi: 10.3389/fmicb.2017.01986

Douville, R., Liu, J., Rothstein, J., and Nath, A. (2011). Identification of active loci of a human endogenous retrovirus in neurons of patients with amyotrophic lateral sclerosis. Ann. Neurol. 69, 141-151. doi: 10.1002/ana.22149

Duarte, E. A. C., Benevides, M. L., Martins, A. L. P., Duarte, E. P., Weller, A. B. S., de Azevedo, L. O. C., et al. (2020). Female sex is strongly associated with cognitive impairment in HIV infection. Neurol. Sci. doi: 10.1007/s10072-020-04705-x [Epub Online ahead of print]

Eimer, W. A., Vijaya Kumar, D. K., Navalpur Shanmugam, N. K., Rodriguez, A. S., Mitchell, T., Washicosky, K. J., et al. (2018). Alzheimer's Disease-Associated beta-Amyloid Is Rapidly Seeded by Herpesviridae to Protect against Brain Infection. Neuron 99:e53.

Elkind, M. S. V., Boehme, A. K., Smith, C. J., Meisel, A., and Buckwalter, M. S. (2020). Infection as a Stroke Risk Factor and Determinant of Outcome After Stroke. Stroke 51, 3156-3168. doi: 10.1161/strokeaha.120.030429

Evans, T. A., and Erwin, J. A. (2020). Retroelement-derived RNA and its role in the brain. Netherland: Elsevier.

Fasching, L., Kapopoulou, A., Sachdeva, R., Petri, R., Jonsson, M. E., Manne, C., et al. (2015). TRIM28 represses transcription of endogenous retroviruses in neural progenitor cells. Cell Rep. 10, 20-28. doi: 10.1016/j.celrep.2014.12.004

Fletcher, N. F., Wilson, G. K., Murray, J., Hu, K., Lewis, A., Reynolds, G. M., et al. (2012). Hepatitis C virus infects the endothelial cells of the blood-brain barrier. Gastroenterology 142:e636.

Frost, B., Hemberg, M., Lewis, J., and Feany, M. B. (2014). Tau promotes neurodegeneration through global chromatin relaxation. Nat. Neurosci. 17, 357-366. doi: 10.1038/nn.3639

Frydecka, D., Krzystek-Korpacka, M., Lubeiro, A., Stramecki, F., Stanczykiewicz, B., Beszlej, J. A., et al. (2018). Profiling inflammatory signatures of schizophrenia: A cross-sectional and meta-analysis study. Brain Behav. Immun. 71, 28-36. doi: 10.1016/j.bbi.2018.05.002

Fujii, Y. R. (2010). RNA Genes: Retroelements and Virally Retroposable microRNAs in Human Embryonic Stem Cells. Open Virol. J. 4, 63-75. doi: $10.2174 / 1874357901004010063$

Fulop, T., Witkowski, J. M., Bourgade, K., Khalil, A., Zerif, E., Larbi, A., et al. (2018). Can an Infection Hypothesis Explain the Beta Amyloid Hypothesis of Alzheimer's Disease? Front. Aging Neurosci. 10:224. doi: 10.3389/fnagi.2018. 00224

Fulop, T., Witkowski, J. M., Larbi, A., Khalil, A., Herbein, G., and Frost, E. H. (2019). Does HIV infection contribute to increased beta-amyloid synthesis and plaque formation leading to neurodegeneration and Alzheimer's disease? J. Neurovirol. 25, 634-647. doi: 10.1007/s13365-019-00732-3

Gannet, L. (2019). The Human Genome Project in The Stanford Encyclopedia of Philosophy (Winter 2019 Edition), ed. E. N. Zalta (Netherland: Elsevier).

Garcia, F., Niebla, G., Romeu, J., Vidal, C., Plana, M., Ortega, M., et al. (1999). Cerebrospinal fluid HIV-1 RNA levels in asymptomatic patients with early stage 
chronic HIV-1 infection: support for the hypothesis of local virus replication. AIDS 13, 1491-1496. doi: 10.1097/00002030-199908200-00008

Garson, J. A., Tuke, P. W., Giraud, P., Paranhos-Baccala, G., and Perron, H. (1998). Detection of virion-associated MSRV-RNA in serum of patients with multiple sclerosis. Lancet 351:33. doi: 10.1016/s0140-6736(98)24001-3

Gentilini, D., Mari, D., Castaldi, D., Remondini, D., Ogliari, G., Ostan, R., et al. (2013). Role of epigenetics in human aging and longevity: genome-wide DNA methylation profile in centenarians and centenarians' offspring. Age 35, 19611973. doi: 10.1007/s11357-012-9463-1

Ghafouri, M., Amini, S., Khalili, K., and Sawaya, B. E. (2006). HIV-1 associated dementia: symptoms and causes. Retrovirology 3:28.

Gim, J. A., Ha, H. S., Ahn, K., Kim, D. S., and Kim, H. S. (2014). GenomeWide Identification and Classification of MicroRNAs Derived from Repetitive Elements. Genom. Inform. 12, 261-267. doi: 10.5808/gi.2014.12.4.261

Godbout, J. P., Chen, J., Abraham, J., Richwine, A. F., Berg, B. M., Kelley, K. W., et al. (2005). Exaggerated neuroinflammation and sickness behavior in aged mice following activation of the peripheral innate immune system. FASEB $\mathrm{J}$. 19, 1329-1331. doi: 10.1096/fj.05-3776fje

Goke, J., and Ng, H. H. (2016). CTRL+INSERT: retrotransposons and their contribution to regulation and innovation of the transcriptome. EMBO Rep. 17, 1131-1144. doi: 10.15252/embr.201642743

Gonzalez-Hernandez, M. J., Cavalcoli, J. D., Sartor, M. A., Contreras-Galindo, R., Meng, F., Dai, M., et al. (2014). Regulation of the human endogenous retrovirus K (HML-2) transcriptome by the HIV-1 Tat protein. J. Virol. 88, 8924-8935. doi: 10.1128/jvi.00556- 14

Gordon, D. E., Jang, G. M., Bouhaddou, M., Xu, J., Obernier, K., O’Meara, M. J., et al. (2020). A SARS-CoV-2-Human Protein-Protein Interaction Map Reveals Drug Targets and Potential Drug-Repurposing. bioRxiv.

Grandi, N., and Tramontano, E. (2017). Type W Human Endogenous Retrovirus (HERV-W) Integrations and Their Mobilization by L1 Machinery: Contribution to the Human Transcriptome and Impact on the Host Physiopathology. Viruses 9:162. doi: 10.3390/v9070162

Groger, V., Emmer, A., Staege, M. S., and Cynis, H. (2021). Endogenous Retroviruses in Nervous System Disorders. Pharmaceuticals 14:70. doi: 10.3390/ ph14010070

Gruchot, J., Kremer, D., and Kury, P. (2019). Neural Cell Responses Upon Exposure to Human Endogenous Retroviruses. Front. Genet. 10:655. doi: 10.3389/fnagi. 2018.00224

Gruchot, J., Kremer, D., and Kury, P. (2020). Human endogenous retroviruses: ammunition for myeloid cells in neurodegenerative diseases? Neural. Regen. Res. $15,1043-1044$. doi: 10.4103/1673-5374.270311

Guadarrama-Ortiz, P., Choreno-Parra, J. A., Sanchez-Martinez, C. M., Pacheco-Sanchez, F. J., Rodriguez-Nava, A. I., and Garcia-Quintero, G. (2020). Neurological Aspects of SARS-CoV-2 Infection: Mechanisms and Manifestations. Front. Neurol. 11:1039. doi: 10.3389/fneur.2020.01039

Gurtler, C., and Bowie, A. G. (2013). Innate immune detection of microbial nucleic acids. Trends Microbiol. 21, 413-420. doi: 10.1016/j.tim.2013.04.004

Hancks, D. C., and Kazazian, H. H. Jr. (2012). Active human retrotransposons: variation and disease. Curr. Opin. Genet. Dev. 22, 191-203. doi: 10.1016/j.gde. 2012.02 .006

Hayashi, K., Sasai, M., and Iwasaki, A. (2015). Toll-like receptor 9 trafficking and signaling for type I interferons requires PIKfyve activity. Int. Immunol. 27, 435-445. doi: 10.1093/intimm/dxv021

Heil, F., Hemmi, H., Hochrein, H., Ampenberger, F., Kirschning, C., Akira, S., et al. (2004). Species-specific recognition of single-stranded RNA via toll-like receptor 7 and 8. Science 303, 1526-1529. doi: 10.1126/science.1093620

Herve, C. A., Lugli, E. B., Brand, A., Griffiths, D. J., and Venables, P. J. (2002). Autoantibodies to human endogenous retrovirus- $\mathrm{K}$ are frequently detected in health and disease and react with multiple epitopes. Clin. Exp. Immunol. 128, 75-82. doi: 10.1046/j.1365-2249.2002.01735.x

Hetze, S., Engel, O., Romer, C., Mueller, S., Dirnagl, U., Meisel, C., et al. (2013). Superiority of preventive antibiotic treatment compared with standard treatment of poststroke pneumonia in experimental stroke: a bed to bench approach. J. Cereb. Blood Flow Metab 33, 846-854. doi: 10.1038/jcbfm.2013.6

Huang, Y. H., Jiang, D., and Huang, J. T. (2020). SARS-CoV-2 Detected in Cerebrospinal Fluid by PCR in a Case of COVID-19 Encephalitis. Brain Behav. Immun. 87:149. doi: 10.1016/j.bbi.2020.05.012
Hurst, T. P., and Magiorkinis, G. (2015). Activation of the innate immune response by endogenous retroviruses. J. Gen. Virol. 96, 1207-1218. doi: 10.1099/jgv.0. 000017

Hurst, T. P., and Magiorkinis, G. (2017). Epigenetic Control of Human Endogenous Retrovirus Expression: Focus on Regulation of Long-Terminal Repeats (LTRs). Viruses 9:130. doi: 10.3390/v9060130

Jakobsson, J., Cordero, M. I., Bisaz, R., Groner, A. C., Busskamp, V., Bensadoun, J. C., et al. (2008). KAP1-mediated epigenetic repression in the forebrain modulates behavioral vulnerability to stress. Neuron 60, 818-831. doi: 10.1016/ j.neuron.2008.09.036

Janssen, R. S., Nwanyanwu, O. C., Selik, R. M., and Stehr-Green, J. K. (1992). Epidemiology of human immunodeficiency virus encephalopathy in the United States. Neurology 42, 1472-1476. doi: 10.1212/wnl.42.8.1472

Jiao, H., Wachsmuth, L., Kumari, S., Schwarzer, R., Lin, J., Eren, R. O., et al. (2020). Z-nucleic-acid sensing triggers ZBP1-dependent necroptosis and inflammation. Nature 580, 391-395. doi: 10.1038/s41586-020-2129-8

Johansson, E. M., Bouchet, D., Tamouza, R., Ellul, P., Morr, A. S., Avignone, E., et al. (2020). Human endogenous retroviral protein triggers deficit in glutamate synapse maturation and behaviors associated with psychosis. Sci. Adv. 6:eabc0708. doi: 10.1126/sciadv.abc0708

Johnston, J. B., Silva, C., Holden, J., Warren, K. G., Clark, A. W., and Power, C. (2001). Monocyte activation and differentiation augment human endogenous retrovirus expression: implications for inflammatory brain diseases. Ann. Neurol. 50, 434-442. doi: 10.1002/ana.1131

Jung, M., and Pfeifer, G. P. (2015). Aging and DNA methylation. BMC Biol. 13:7. doi: 10.1186/s12915-015-0118-4

Kammerer, U., Germeyer, A., Stengel, S., Kapp, M., and Denner, J. (2011). Human endogenous retrovirus $\mathrm{K}$ (HERV-K) is expressed in villous and extravillous cytotrophoblast cells of the human placenta. J. Reprod. Immunol. 91, 1-8.

Kaneko, N., Satta, S., Komuro, Y., Muthukrishnan, S. D., Kakarla, V., Guo, L., et al. (2021). Flow-Mediated Susceptibility and Molecular Response of Cerebral Endothelia to SARS-CoV-2 Infection. Stroke 52, 260-270. doi: 10. 1161/strokeaha.120.032764

Katyal, N., Narula, N., Acharya, S., and Govindarajan, R. (2020). Neuromuscular Complications With SARS-COV-2 Infection: A Review. Front. Neurol. 11:1052. doi: $10.3389 /$ fneur.2020.01052

Kennedy, P. G., and Cohrs, R. J. (2010). Varicella-zoster virus human ganglionic latency: a current summary. J. Neurovirol. 16, 411-418. doi: 10.1007/ bf03210846

Koskenvuo, M., Mottonen, M., Rahiala, J., Saarinen-Pihkala, U. M., Riikonen, P., Waris, M., et al. (2008). Respiratory viral infections in children with leukemia. Pediatr. Infect. Dis. J. 27, 974-980.

Kozak, C. A. (1985). Retroviruses as chromosomal genes in the mouse. Adv. Cancer Res. 44, 295-336. doi: 10.1016/s0065-230x(08)60030-5

Kraft-Terry, S. D., Stothert, A. R., Buch, S., and Gendelman, H. E. (2010). HIV-1 neuroimmunity in the era of antiretroviral therapy. Neurobiol. Dis. $37,542-548$. doi: 10.1016/j.nbd.2009.12.015

Kremer, D., Forster, M., Schichel, T., Gottle, P., Hartung, H. P., Perron, H., et al. (2015). The neutralizing antibody GNbAC1 abrogates HERV-W envelope protein-mediated oligodendroglial maturation blockade. Mult. Scler 21, 12001203. doi: $10.1177 / 1352458514560926$

Kremer, D., Gruchot, J., Weyers, V., Oldemeier, L., Gottle, P., Healy, L., et al. (2019). pHERV-W envelope protein fuels microglial cell-dependent damage of myelinated axons in multiple sclerosis. Proc. Natl. Acad. Sci. U. S. A. 116, 15216-15225. doi: 10.1073/pnas.1901283116

Kremer, D., Schichel, T., Forster, M., Tzekova, N., Bernard, C., van der Valk, P., et al. (2013). Human endogenous retrovirus type $\mathrm{W}$ envelope protein inhibits oligodendroglial precursor cell differentiation. Ann. Neurol. 74, 721-732. doi: 10.1002/ana.23970

Kriesel, J. D., Bhetariya, P. J., Chan, B. K., Wilson, T., and Fischer, K. F. (2017). Enrichment of Retroviral Sequences in Brain Tissue from Patients with Severe Demyelinating Diseases. J. Emerg. Dis. Virol. 3:10.16966/24731846.132

Kurnosov, A. A., Ustyugova, S. V., Nazarov, V. I., Minervina, A. A., Komkov, A. Y., Shugay, M., et al. (2015). The evidence for increased L1 activity in the site of human adult brain neurogenesis. PLoS One 10:e0117854. doi: 10.1371/journal. pone. 0117854 
Kury, P., Nath, A., Creange, A., Dolei, A., Marche, P., Gold, J., et al. (2018). Human Endogenous Retroviruses in Neurological Diseases. Trends Mol. Med. 24, 379-394.

Lafon, M., Jouvin-Marche, E., Marche, P. N., and Perron, H. (2002). Human viral superantigens: to be or not to be transactivated? Trends Immunol. 23, 238-239. doi: 10.1016/s1471-4906(02)02207-x

Lafon, M., Lafage, M., Martinez-Arends, A., Ramirez, R., Vuillier, F., Charron, D., et al. (1992). Evidence for a viral superantigen in humans. Nature 358, 507-510.

Lan, J., Ge, J., Yu, J., Shan, S., Zhou, H., Fan, S., et al. (2020). Structure of the SARSCoV-2 spike receptor-binding domain bound to the ACE2 receptor. Nature 581, 215-220.

Lancman, G., Mascarenhas, J., and Bar-Natan, M. (2020). Severe COVID-19 virus reactivation following treatment for $\mathrm{B}$ cell acute lymphoblastic leukemia. J. Hematol. Oncol. 13:131.

Laperriere, D., Wang, T. T., White, J. H., and Mader, S. (2007). Widespread Alu repeat-driven expansion of consensus DR2 retinoic acid response elements during primate evolution. BMC Genomics 8:23. doi: 10.1186/1471-21 64-8-23

Larochelle, C., Alvarez, J. I., and Prat, A. (2011). How do immune cells overcome the blood-brain barrier in multiple sclerosis? FEBS Lett. 585, 3770-3780. doi: 10.1016/j.febslet.2011.04.066

Lavie, L., Kitova, M., Maldener, E., Meese, E., and Mayer, J. (2005). CpG methylation directly regulates transcriptional activity of the human endogenous retrovirus family HERV-K(HML-2). J. Virol. 79, 876-883. doi: 10.1128/jvi.79.2. 876-883.2005

Lawrence, D. M., and Major, E. O. (2002). HIV-1 and the brain: connections between HIV-1-associated dementia, neuropathology and neuroimmunology. Microbes Infect. 4, 301-308. doi: 10.1016/s1286-4579(02)01542-3

Leboyer, M., Tamouza, R., Charron, D., Faucard, R., and Perron, H. (2013). Human endogenous retrovirus type $\mathrm{W}(\mathrm{HERV}-\mathrm{W})$ in schizophrenia: a new avenue of research at the gene-environment interface. World J. Biol. Psychiatry 14, 80-90. doi: $10.3109 / 15622975.2010 .601760$

Lee, J. T. (2012). Epigenetic regulation by long noncoding RNAs. Science 338, 1435-1439. doi: 10.1126/science.1231776

Levet, S., Charvet, B., Bertin, A., Deschaumes, A., Perron, H., and Hober, D. (2019). Human Endogenous Retroviruses and Type 1 Diabetes. Curr. Diab. Rep. 19:141. doi: $10.1201 / 9781498713801-13$

Levet, S., Medina, J., Joanou, J., Demolder, A., Queruel, N., Reant, K., et al. (2017). An ancestral retroviral protein identified as a therapeutic target in type-1 diabetes. JCI Insight 2:e94386.

Lev-Maor, G., Sorek, R., Shomron, N., and Ast, G. (2003). The birth of an alternatively spliced exon: 3' splice-site selection in Alu exons. Science 300, 1288-1291. doi: 10.1126/science. 1082588

Li, F., Nellaker, C., Sabunciyan, S., Yolken, R. H., Jones-Brando, L., Johansson, A. S., et al. (2014). Transcriptional derepression of the ERVWE1 locus following influenza A virus infection. J. Virol. 88, 4328-4337. doi: 10.1128/jvi.03628-13

Li, F., Sabunciyan, S., Yolken, R. H., Lee, D., Kim, S., and Karlsson, H. (2019). Transcription of human endogenous retroviruses in human brain by RNA-seq analysis. PLoS One 14:e207353. doi: 10.1371/journal.pone.0207353

Li, W., Lee, M. H., Henderson, L., Tyagi, R., Bachani, M., Steiner, J., et al. (2015). Human endogenous retrovirus-K contributes to motor neuron disease. Sci. Transl. Med. 7:307ra153. doi: 10.1126/scitranslmed.aac8201

Li, W., Prazak, L., Chatterjee, N., Gruninger, S., Krug, L., Theodorou, D., et al. (2013). Activation of transposable elements during aging and neuronal decline in Drosophila. Nat. Neurosci. 16, 529-531. doi: 10.1038/nn.3368

Limosin, F., Rouillon, F., Payan, C., Cohen, J. M., and Strub, N. (2003). Prenatal exposure to influenza as a risk factor for adult schizophrenia. Acta Psychiatr. Scand. 107, 331-335. doi: 10.1034/j.1600-0447.2003.00052.x

Lippi, A., Domingues, R., Setz, C., Outeiro, T. F., and Krisko, A. (2020). SARSCoV-2: At the Crossroad Between Aging and Neurodegeneration. Mov. Disord. 35, 716-720. doi: $10.1002 / \mathrm{mds} .28084$

Liu, C., Chen, Y., Li, S., Yu, H., Zeng, J., Wang, X., et al. (2013). Activation of elements in HERV-W family by caffeine and aspirin. Virus Genes 47, 219-227. doi: 10.1007/s11262-013-0939-6

Liu, X., Liu, Y., Chen, K., Yan, S., Bai, X., Li, J., et al. (2020). Efficacy of ACEIs/ARBs vs CCBs on the progression of COVID-19 patients with hypertension in Wuhan: A hospital-based retrospective cohort study. J. Med. Virol. 93, 854-862. doi: $10.1002 / j m v .26315$
Lombard, D. B., Chua, K. F., Mostoslavsky, R., Franco, S., Gostissa, M., and Alt, F. W. (2005). DNA repair, genome stability, and aging. Cell 120, 497-512.

Looker, K. J., Magaret, A. S., May, M. T., Turner, K. M., Vickerman, P., Gottlieb, S. L., et al. (2015). Global and Regional Estimates of Prevalent and Incident Herpes Simplex Virus Type 1 Infections in 2012. PLoS One 10:e0140765. doi: 10.1371/journal.pone. 0140765

Louveau, A., Harris, T. H., and Kipnis, J. (2015). Revisiting the Mechanisms of CNS Immune Privilege. Trends Immunol. 36, 569-577. doi: 10.1016/j.it.2015.08.006

Lovheim, H., Gilthorpe, J., Adolfsson, R., Nilsson, L. G., and Elgh, F. (2015). Reactivated herpes simplex infection increases the risk of Alzheimer's disease. Alzheimers Dement 11, 593-599. doi: 10.1016/j.jalz.2014.04.522

Lu, L., Xiong, W., Liu, D., Liu, J., Yang, D., Li, N., et al. (2020). New onset acute symptomatic seizure and risk factors in coronavirus disease 2019: A retrospective multicenter study. Epilepsia 61, e49-e53.

Lusso, P., di Marzo, Veronese, F., Ensoli, B., Franchini, G., Jemma, C., et al. (1990). Expanded HIV-1 cellular tropism by phenotypic mixing with murine endogenous retroviruses. Science 247, 848-852. doi: 10.1126/science. 2305256

MacGowan, D. J., Scelsa, S. N., Imperato, T. E., Liu, K. N., Baron, P., and Polsky, B. (2007). A controlled study of reverse transcriptase in serum and CSF of HIV-negative patients with ALS. Neurology 68, 1944-1946. doi: 10.1212/01. wnl.0000263188.77797.99

Mahmood, W., Erichsen, L., Ott, P., Schulz, W. A., Fischer, J. C., Arauzo-Bravo, M. J., et al. (2020). Aging-associated distinctive DNA methylation changes of LINE-1 retrotransposons in pure cell-free DNA from human blood. Sci. Rep. 10:22127.

Mak, M., Samochowiec, J., Frydecka, D., Pelka-Wysiecka, J., Szmida, E., Karpinski, P., et al. (2019). First-episode schizophrenia is associated with a reduction of HERV-K methylation in peripheral blood. Psychiatry Res. 271, 459-463. doi: 10.1016/j.psychres.2018.12.012

Mameli, G., Erre, G. L., Caggiu, E., Mura, S., Cossu, D., Bo, M., et al. (2017). Identification of a HERV-K env surface peptide highly recognized in Rheumatoid Arthritis (RA) patients: a cross-sectional case-control study. Clin. Exp. Immunol. 189, 127-131. doi: 10.1111/cei.12964

Mameli, G., Poddighe, L., Mei, A., Uleri, E., Sotgiu, S., Serra, C., et al. (2012). Expression and activation by Epstein Barr virus of human endogenous retroviruses-W in blood cells and astrocytes: inference for multiple sclerosis. PLoS One 7:e44991. doi: 10.1371/journal.pone.0044991

Mancuso, R., Delbue, S., Borghi, E., Pagani, E., Calvo, M. G., Caputo, D., et al. (2007). Increased prevalence of varicella zoster virus DNA in cerebrospinal fluid from patients with multiple sclerosis. J. Med. Virol. 79, 192-199. doi: 10.1002/jmv. 20777

Manghera, M., and Douville, R. N. (2013). Endogenous retrovirus-K promoter: a landing strip for inflammatory transcription factors? Retrovirology 10:16.

Manghera, M., Ferguson, J., and Douville, R. (2015). ERVK polyprotein processing and reverse transcriptase expression in human cell line models of neurological disease. Viruses 7, 320-332. doi: 10.3390/v7010320

Manghera, M., Ferguson-Parry, J., Lin, R., and Douville, R. N. (2016). NFkappaB and IRF1 Induce Endogenous Retrovirus K Expression via InterferonStimulated Response Elements in Its 5'. Long Terminal. Repeat. J. Virol. 90, 9338-9349. doi: 10.1128/jvi.01503-16

Marrodan, M., Bensi, C., Pappolla, A., Rojas, J. I., Gaitan, M. I., Ysrraelit, M. C., et al. (2019). Disease activity impacts disability progression in primary progressive multiple sclerosis. Mult. Scler. Relat. Disord. 39:101892. doi: 10. 1016/j.msard.2019.101892

Masliah, E., Achim, C. L., Ge, N., DeTeresa, R., Terry, R. D., and Wiley, C. A. (1992). Spectrum of human immunodeficiency virus-associated neocortical damage. Ann. Neurol. 32, 321-329. doi: 10.1002/ana.410320304

McCormick, A. L., Brown, R. H. Jr., Cudkowicz, M. E., Al-Chalabi, A., and Garson, J. A. (2008). Quantification of reverse transcriptase in ALS and elimination of a novel retroviral candidate. Neurology 70, 278-283. doi: 10.1212/01.wnl. 0000297552.13219.b4

Mehler, M. F., and Mattick, J. S. (2007). Noncoding RNAs and RNA editing in brain development, functional diversification, and neurological disease. Physiol. Rev. 87, 799-823. doi: 10.1152/physrev.00036.2006

Mi, S., Lee, X., Li, X., Veldman, G. M., Finnerty, H., Racie, L., et al. (2000). Syncytin is a captive retroviral envelope protein involved in human placental morphogenesis. Nature 403, 785-789. doi: 10.1038/35001608 
Miyazawa, M., and Fujisawa, R. (1994). Physiology and pathology of host immune responses to exogenous and endogenous murine retroviruses-from gene fragments to epitopes. Tohoku. J. Exp. Med. 173, 91-103. doi: 10.1620/tjem. 173.91

Monde, K., Contreras-Galindo, R., Kaplan, M. H., Markovitz, D. M., and Ono, A. (2012). Human endogenous retrovirus K Gag coassembles with HIV-1 Gag and reduces the release efficiency and infectivity of HIV-1. J. Virol. 86, 11194-11208. doi: 10.1128/jvi.00301-12

Moon, U. Y., Park, S. J., Oh, S. T., Kim, W. U., Park, S. H., Lee, S. H., et al. (2004). Patients with systemic lupus erythematosus have abnormally elevated Epstein-Barr virus load in blood. Arthritis. Res. Ther. 6, R295-R302.

Morandi, E., Tanasescu, R., Tarlinton, R. E., Constantinescu, C. S., Zhang, W., Tench, C., et al. (2017). The association between human endogenous retroviruses and multiple sclerosis: A systematic review and meta-analysis. PLoS One 12:e0172415. doi: 10.1371/journal.pone.0172415

Moriguchi, T., Harii, N., Goto, J., Harada, D., Sugawara, H., Takamino, J., et al. (2020). A first case of meningitis/encephalitis associated with SARSCoronavirus-2. Int. J. Infect. Dis. 94, 55-58.

Moulignier, A., Moulonguet, A., Pialoux, G., and Rozenbaum, W. (2001). Reversible ALS-like disorder in HIV infection. Neurology 57, 995-1001. doi: 10.1212/wnl.57.6.995

Mueller, O., Moore, D. W., Giovannucci, J., Etter, A. R., Peterson, E. M., Mudge, A., et al. (2018). Expression of Human Endogenous Retroviruses in Peripheral Leukocytes During the Menstrual Cycle Suggests Coordinated Hormonal Regulation. AIDS Res. Hum. Retrovir. 34, 909-911. doi: 10.1089/aid.2018.0059

Muotri, A. R., Chu, V. T., Marchetto, M. C., Deng, W., Moran, J. V., and Gage, F. H. (2005). Somatic mosaicism in neuronal precursor cells mediated by L1 retrotransposition. Nature 435, 903-910. doi: 10.1038/nature03663

Murphy, J. V., and Yunis, E. J. (1976). Encephalopathy following measles infection in children with chronic illness. J. Pediatr. 88, 937-942. doi: 10.1016/s00223476(76)81045-1

Murray, R. S., Brown, B., Brian, D., and Cabirac, G. F. (1992). Detection of coronavirus RNA and antigen in multiple sclerosis brain. Ann. Neurol. 31, 525-533. doi: 10.1002/ana.410310511

Nath, A., and Smith, B. (2021). Neurological issues during COVID-19: An overview. Neurosci. Lett. 742:135533. doi: 10.1016/j.neulet.2020.135533

Navia, B. A., Jordan, B. D., and Price, R. W. (1986). The AIDS dementia complex: I. Clin. Feat. Ann. Neurol. 19, 517-524.

Nellaker, C., Yao, Y., Jones-Brando, L., Mallet, F., Yolken, R. H., and Karlsson, H. (2006). Transactivation of elements in the human endogenous retrovirus W family by viral infection. Retrovirology 3:44.

Nettis, M. A., Pariante, C. M., and Mondelli, V. (2020). Early-Life Adversity, Systemic Inflammation and Comorbid Physical and Psychiatric Illnesses of Adult Life. Curr. Top. Behav. Neurosci. 44, 207-225. doi: 10.1007/7854_2019_ 89

Nexo, B. A., Christensen, T., Frederiksen, J., Moller-Larsen, A., Oturai, A. B., Villesen, P., et al. (2011). The etiology of multiple sclerosis: genetic evidence for the involvement of the human endogenous retrovirus HERV-Fc1. PLoS One 6:e16652. doi: 10.1371/journal.pone.0016652

Nookala, A. R., Mitra, J., Chaudhari, N. S., Hegde, M. L., and Kumar, A. (2017). An Overview of Human Immunodeficiency Virus Type 1-Associated Common Neurological Complications: Does Aging Pose a Challenge? J. Alzheimers Dis. 60, S169-S193.

Norris, J., Fan, D., Aleman, C., Marks, J. R., Futreal, P. A., Wiseman, R. W., et al. (1995). Identification of a new subclass of Alu DNA repeats which can function as estrogen receptor-dependent transcriptional enhancers. J. Biol. Chem. 270, 22777-22782.

O’Carroll, I. P., Fan, L., Kroupa, T., McShane, E. K., Theodore, C., Yates, E. A., et al. (2020). Structural Mimicry Drives HIV-1 Rev-Mediated HERV-K Expression. J. Mol. Biol. 432:166711.

Odaka, T. (1975). Genetic transmission of endogenous N- and B-tropic murine leukemia viruses in low-leukemic strain C57BL/6. J. Virol. 15, 332-337.

Ogasawara, H., Hishikawa, T., Sekigawa, I., Hashimoto, H., Yamamoto, N., and Maruyama, N. (2000). Sequence analysis of human endogenous retrovirus clone 4-1 in systemic lupus erythematosus. Autoimmunity 33, 15-21.

Ohka, S., Yang, W. X., Terada, E., Iwasaki, K., and Nomoto, A. (1998). Retrograde transport of intact poliovirus through the axon via the fast transport system. Virology 250, 67-75.
Ortega, M., and Ances, B. M. (2014). Role of HIV in amyloid metabolism. J. Neuroimmune Pharmacol. 9, 483-491.

Owen, M. J., Sawa, A., and Mortensen, P. B. (2016). Schizophrenia. Lancet 388, 86-97.

Oxley, T. J., Mocco, J., Majidi, S., Kellner, C. P., Shoirah, H., Singh, I. P., et al. (2020). Large-Vessel Stroke as a Presenting Feature of Covid-19 in the Young. N. Engl. J. Med. 382:e60.

Pearce, J., Murray, C., and Larkin, W. (2019). Childhood adversity and trauma: experiences of professionals trained to routinely enquire about childhood adversity. Heliyon 5:e01900

Perron, H., Garson, J. A., Bedin, F., Beseme, F., Paranhos-Baccala, G., KomurianPradel, F., et al. (1997). Molecular identification of a novel retrovirus repeatedly isolated from patients with multiple sclerosis. The Collaborative Research Group on Multiple Sclerosis. Proc. Natl. Acad. Sci. U. S. A. 94, 7583-7588.

Perron, H., Germi, R., Bernard, C., Garcia-Montojo, M., Deluen, C., Farinelli, L., et al. (2012a). Human endogenous retrovirus type $\mathrm{W}$ envelope expression in blood and brain cells provides new insights into multiple sclerosis disease. Mult. Scler. 18, 1721-1736.

Perron, H., Hamdani, N., Faucard, R., Lajnef, M., Jamain, S., Daban-Huard, C., et al. (2012b). Molecular characteristics of Human Endogenous Retrovirus type-W in schizophrenia and bipolar disorder. Transl. Psych. 2:e201.

Perron, H., Jouvin-Marche, E., Michel, M., Ounanian-Paraz, A., Camelo, S., Dumon, A., et al. (2001). Multiple sclerosis retrovirus particles and recombinant envelope trigger an abnormal immune response in vitro, by inducing polyclonal Vbeta16 T-lymphocyte activation. Virology 287, 321-332.

Perron, H., Mekaoui, L., Bernard, C., Veas, F., Stefas, I., and Leboyer, M. (2008). Endogenous retrovirus type W GAG and envelope protein antigenemia in serum of schizophrenic patients. Biol. Psych. 64, 1019-1023.

Ramasamy, R., Joseph, B., and Whittall, T. (2017). Potential molecular mimicry between the human endogenous retrovirus $\mathrm{W}$ family envelope proteins and myelin proteins in multiple sclerosis. Immunol. Lett. 183, 79-85. doi: 10.1016/ j.imlet.2017.02.003

Rasmussen, H. B. (1997). Interactions between Exogenous and Endogenous Retroviruses. J. Biomed. Sci. 4, 1-8. doi: 10.1007/BF02255587

Readhead, B., Haure-Mirande, J. V., Funk, C. C., Richards, M. A., Shannon, P., Haroutunian, V., et al. (2018). Multiscale Analysis of Independent Alzheimer's Cohorts Finds Disruption of Molecular, Genetic, and Clinical Networks by Human Herpesvirus. Neuron 99:e67. doi: 10.1016/j.neuron.2018.05.023

Ren, R., and Racaniello, V. R. (1992). Poliovirus spreads from muscle to the central nervous system by neural pathways. J. Infect. Dis. 166, 747-752. doi: 10.1093/infdis/166.4.747

Richardson, S. R., Morell, S., and Faulkner, G. J. (2014). L1 retrotransposons and somatic mosaicism in the brain. Annu. Rev. Genet. 48, 1-27. doi: 10.1146/ annurev-genet-120213-092412

Rigby, R. E., Webb, L. M., Mackenzie, K. J., Li, Y., Leitch, A., Reijns, M. A., et al. (2014). RNA:DNA hybrids are a novel molecular pattern sensed by TLR9. EMBO J. 33, 542-558. doi: 10.1002/embj.201386117

Robertson, K. R., Smurzynski, M., Parsons, T. D., Wu, K., Bosch, R. J., Wu, J., et al. (2007). The prevalence and incidence of neurocognitive impairment in the HAART era. AIDS 21, 1915-1921. doi: 10.1097/QAD.0b013e32828e4e27

Rodriguez, C., Gouilh, M. A., Weiss, N., Stroer, S., Mokhtari, K., Seilhean, D., et al. (2020). Fatal Measles Inclusion-Body Encephalitis in Adult with Untreated AIDS. France. Emerg. Infect. Dis. 26, 2231-2234. doi: 10.3201/eid2609.200366

Rolland, A., Jouvin-Marche, E., Saresella, M., Ferrante, P., Cavaretta, R., Creange, A., et al. (2005). Correlation between disease severity and in vitro cytokine production mediated by MSRV (multiple sclerosis associated retroviral element) envelope protein in patients with multiple sclerosis. J. Neuroimmunol. 160, 195-203. doi: 10.1016/j.jneuroim.2004.10.019

Rolland, A., Jouvin-Marche, E., Viret, C., Faure, M., Perron, H., and Marche, P. N. (2006). The envelope protein of a human endogenous retrovirus-W family activates innate immunity through CD14/TLR4 and promotes Th1like responses. J. Immunol. 176, 7636-7644. doi: 10.4049/jimmunol.176.1 2.7636

Romer, C., Engel, O., Winek, K., Hochmeister, S., Zhang, T., Royl, G., et al. (2015). Blocking stroke-induced immunodeficiency increases CNS antigen-specific autoreactivity but does not worsen functional outcome after experimental stroke. J. Neurosci. 35, 7777-7794. doi: 10.1523/JNEUROSCI. $1532-14.2015$ 
Romer, C., Singh, M., Hurst, L. D., and Izsvak, Z. (2017). How to tame an endogenous retrovirus: HERVH and the evolution of human pluripotency. Curr. Opin. Virol. 25, 49-58. doi: 10.1016/j.coviro.2017.07.001

Ruprecht, K., Obojes, K., Wengel, V., Gronen, F., Kim, K. S., Perron, H., et al. (2006). Regulation of human endogenous retrovirus $\mathrm{W}$ protein expression by herpes simplex virus type 1: implications for multiple sclerosis. J. Neurovirol. 12, 65-71. doi: 10.1080/13550280600614973

Sandstrom, T. S., Ranganath, N., and Angel, J. B. (2017). Impairment of the type I interferon response by HIV-1: Potential targets for HIV eradication. Cytokine Growth Factor. Rev. 37, 1-16. doi: 10.1016/j.cytogfr.2017.04.004

Sankowski, R., Strohl, J. J., Huerta, T. S., Nasiri, E., Mazzarello, A. N., D’Abramo, C., et al. (2019). Endogenous retroviruses are associated with hippocampusbased memory impairment. Proc. Natl. Acad. Sci. U. S. A. 116, 25982-25990. doi: 10.1073/pnas.1822164116

Saresella, M., Rolland, A., Marventano, I., Cavarretta, R., Caputo, D., Marche, P., et al. (2009). Multiple sclerosis-associated retroviral agent (MSRV)-stimulated cytokine production in patients with relapsing-remitting multiple sclerosis. Mult. Scler. 15, 443-447. doi: 10.1177/1352458508100840

Schizophrenia Working Group of the Psychiatric Genomics, C. (2014). Biological insights from 108 schizophrenia-associated genetic loci. Nature 511, 421-427.

Schwartzberg, P., Colicelli, J., and Goff, S. P. (1985). Recombination between a defective retrovirus and homologous sequences in host DNA: reversion by patch repair. J. Virol. 53, 719-726. doi: 10.1128/JVI.53.3.719-726. 1985

Shekarian, T., Valsesia-Wittmann, S., Brody, J., Michallet, M. C., Depil, S., Caux, C., et al. (2017). Pattern recognition receptors: immune targets to enhance cancer immunotherapy. Ann. Oncol. 28, 1756-1766. doi: 10.1093/annonc/mdx179

Shen, S., Lin, L., Cai, J. J., Jiang, P., Kenkel, E. J., Stroik, M. R., et al. (2011). Widespread establishment and regulatory impact of Alu exons in human genes. Proc. Natl. Acad. Sci. U. S. A. 108, 2837-2842. doi: 10.1073/pnas. 1012834108

Shu, M., Du, T., Zhou, G., and Roizman, B. (2015). Role of activating transcription factor 3 in the synthesis of latency-associated transcript and maintenance of herpes simplex virus 1 in latent state in ganglia. Proc. Natl. Acad. Sci. U. S. A. 112, E5420-E5426.

Sico, J. J., Chang, C. C., So-Armah, K., Justice, A. C., Hylek, E., Skanderson, M., et al. (2015). HIV status and the risk of ischemic stroke among men. Neurology 84, 1933-1940. doi: 10.1212/WNL.0000000000001560

Sigurdsson, B. (1954). RIDA, A CHRONIC ENCEPHALITIS OF SHEEP. With General Remarks on Infections Which Develop Slowly and Some of Their Special Characteristics. Br. Vet. J. 110, 341-354. doi: 10.1016/S0007-1935(17) 50172-4

Sotgiu, S., Mameli, G., Serra, C., Zarbo, I. R., Arru, G., and Dolei, A. (2010). Multiple sclerosis-associated retrovirus and progressive disability of multiple sclerosis. Mult. Scler 16, 1248-1251.

Spencer, T. E., Mura, M., Gray, C. A., Griebel, P. J., and Palmarini, M. (2003). Receptor usage and fetal expression of ovine endogenous betaretroviruses: implications for coevolution of endogenous and exogenous retroviruses. J. Virol. 77, 749-753.

Srinivasachar Badarinarayan, S., Shcherbakova, I., Langer, S., Koepke, L., Preising, A., Hotter, D., et al. (2020). HIV-1 infection activates endogenous retroviral promoters regulating antiviral gene expression. Nucleic Acids Res. 48, 1089010908.

Steiner, I., Kennedy, P. G., and Pachner, A. R. (2007). The neurotropic herpes viruses: herpes simplex and varicella-zoster. Lancet. Neurol. 6, 1015-1028. doi: 10.1016/S1474-4422(07)70267-3

Streit, W. J., Sammons, N. W., Kuhns, A. J., and Sparks, D. L. (2004). Dystrophic microglia in the aging human brain. Glia 45, 208-212. doi: 10.1002/glia.10319

Su, S., Wong, G., Shi, W., Liu, J., Lai, A. C. K., Zhou, J., et al. (2016). Epidemiology, Genetic Recombination, and Pathogenesis of Coronaviruses. Trends Microbiol. $24,490-502$.

Sun, W., Samimi, H., Gamez, M., Zare, H., and Frost, B. (2018). Pathogenic tau-induced piRNA depletion promotes neuronal death through transposable element dysregulation in neurodegenerative tauopathies. Nat. Neurosci. 21, 1038-1048.

Sutkowski, N., Conrad, B., Thorley-Lawson, D. A., and Huber, B. T. (2001). Epstein-Barr virus transactivates the human endogenous retrovirus HERV-K18 that encodes a superantigen. Immunity 15, $579-589$.
Tai, A. K., Luka, J., Ablashi, D., and Huber, B. T. (2009). HHV-6A infection induces expression of HERV-K18-encoded superantigen. J. Clin. Virol. 46, 47-48.

Takahashi, K., Wesselingh, S. L., Griffin, D. E., McArthur, J. C., Johnson, R. T., and Glass, J. D. (1996). Localization of HIV-1 in human brain using polymerase chain reaction/in situ hybridization and immunocytochemistry. Ann. Neurol. 39, 705-711. doi:

Takeshita, Y., and Ransohoff, R. M. (2012). Inflammatory cell trafficking across the blood-brain barrier: chemokine regulation and in vitro models. Immunol. Rev. 248, 228-239. doi:

Tam, O. H., Ostrow, L. W., and Gale Hammell, M. (2019). Diseases of the nERVous system: retrotransposon activity in neurodegenerative disease. Mob DNA 10:32. doi:

Tang, D., Kang, R., Coyne, C. B., Zeh, H. J., and Lotze, M. T. (2012). PAMPs and DAMPs: signal 0s that spur autophagy and immunity. Immunol. Rev. 249, 158-175.

Taylor, J. P., Brown, R. H. Jr., and Cleveland, D. W. (2016). Decoding ALS: from genes to mechanism. Nature 539, 197-206.

Toborek, M., Lee, Y. W., Flora, G., Pu, H., Andras, I. E., Wylegala, E., et al. (2005). Mechanisms of the blood-brain barrier disruption in HIV-1 infection. Cell Mol. Neurobiol. 25, 181-199.

Toufaily, C., Landry, S., Leib-Mosch, C., Rassart, E., and Barbeau, B. (2011). Activation of LTRs from different human endogenous retrovirus (HERV) families by the HTLV-1 tax protein and T-cell activators. Viruses 3, 2146-2159.

Tovo, P. A., Garazzino, S., Dapra, V., Alliaudi, C., Silvestro, E., Calvi, C., et al. (2020). Chronic HCV Infection Is Associated with Overexpression of Human Endogenous Retroviruses that Persists after Drug-Induced Viral Clearance. Int. J. Mol. Sci. 21:3980.

Turelli, P., Castro-Diaz, N., Marzetta, F., Kapopoulou, A., Raclot, C., Duc, J., et al. (2014). Interplay of TRIM28 and DNA methylation in controlling human endogenous retroelements. Genome Res. 24, 1260-1270.

Uleri, E., Mei, A., Mameli, G., Poddighe, L., Serra, C., and Dolei, A. (2014). HIV Tat acts on endogenous retroviruses of the $\mathrm{W}$ family and this occurs via Toll-like receptor 4: inference for neuroAIDS. AIDS 28, 2659-2670.

Valdes-Ferre, S. I., Benkendorff, A., and Sankowski, R. (2020). Persistent inflammatory states and their implications in brain disease. Curr. Opin. Neurol. $33,341-346$.

van Horssen, J., van der Pol, S., Nijland, P., Amor, S., and Perron, H. (2016). Human endogenous retrovirus $\mathrm{W}$ in brain lesions: Rationale for targeted therapy in multiple sclerosis. Mult. Scler. Relat. Disord. 8, 11-18. doi: 10.1016/j.msard. 2016.04.006

van Riel, D., Verdijk, R., and Kuiken, T. (2015). The olfactory nerve: a shortcut for influenza and other viral diseases into the central nervous system. J. Pathol. 235, 277-287. doi: 10.1002/path.4461

Verma, A., and Berger, J. R. (2006). ALS syndrome in patients with HIV-1 infection. J. Neurol. Sci. 240, 59-64. doi: 10.1016/j.jns.2005.09.005

Verma, S., Lo, Y., Chapagain, M., Lum, S., Kumar, M., Gurjav, U., et al. (2009). West Nile virus infection modulates human brain microvascular endothelial cells tight junction proteins and cell adhesion molecules: Transmigration across the in vitro blood-brain barrier. Virology 385, 425-433. doi: 10.1016/j.virol. 2008.11.047

Villarreal, L. P. (2011). Viral ancestors of antiviral systems. Viruses 3, 1933-1958. doi: $10.3390 / \mathrm{v} 3101933$

Wald, A., and Corey, L. (2007). "Persistence in the population: epidemiology, transmission," in In Human Herpesviruses: Biology, Therapy, and Immunoprophylaxis, eds A. Arvin, G. Campadelli-Fiume, E. Mocarski, P. S. Moore, B. Roizman, R. Whitley, et al. (Cambridge:Cambridge Univeraity).

Walker, D. K., Bowers, S. J., Mitchell, R. J., Potchoiba, M. J., Schroeder, C. M., and Small, H. F. (2008). Preclinical assessment of the distribution of maraviroc to potential human immunodeficiency virus (HIV) sanctuary sites in the central nervous system (CNS) and gut-associated lymphoid tissue (GALT). Xenobiotica 38, 1330-1339. doi: 10.1080/00498250802447409

Wang, J., Xie, G., Singh, M., Ghanbarian, A. T., Rasko, T., Szvetnik, A., et al. (2014). Primate-specific endogenous retrovirus-driven transcription defines naive-like stem cells. Nature 516, 405-409. doi: 10.1038/nature13804

Wang, T., Medynets, M., Johnson, K. R., Doucet-O’Hare, T. T., DiSanza, B., Li, W., et al. (2020). Regulation of stem cell function and neuronal differentiation by HERV-K via mTOR pathway. Proc. Natl. Acad. Sci. U. S. A. 117, 17842-17853. doi: 10.1073/pnas.2002427117 
Watkins, B. A., Dorn, H. H., Kelly, W. B., Armstrong, R. C., Potts, B. J., Michaels, F., et al. (1990). Specific tropism of HIV-1 for microglial cells in primary human brain cultures. Science 249, 549-553. doi: 10.1126/science.2200125

Wei, W., Gilbert, N., Ooi, S. L., Lawler, J. F., Ostertag, E. M., Kazazian, H. H., et al. (2001). Human L1 retrotransposition: cis preference versus trans complementation. Mol. Cell Biol. 21, 1429-1439. doi: 10.1128/MCB.21.4.14291439.2001

Weiss, R. A., Clapham, P., Nagy, K., and Hoshino, H. (1985). Envelope properties of human T-cell leukemia viruses. Curr. Top. Microbiol. Immunol. 115, 235-246. doi: 10.1007/978-3-642-70113-9_15

Wiley, C. A. (2020). Emergent Viral Infections of the CNS. J. Neuropathol. Exp. Neurol. 79, 823-842. doi: 10.1093/jnen/nlaa054

Wiley, C. A., Schrier, R. D., Nelson, J. A., Lampert, P. W., and Oldstone, M. B. (1986). Cellular localization of human immunodeficiency virus infection within the brains of acquired immune deficiency syndrome patients. Proc. Natl. Acad. Sci. U. S. A. 83, 7089-7093. doi: 10.1073/pnas.83.18.7089

Wu, J., Petralia, R. S., Kurushima, H., Patel, H., Jung, M. Y., Volk, L., et al. (2011). Arc/Arg3.1 regulates an endosomal pathway essential for activity-dependent beta-amyloid generation. Cell 147, 615-628. doi: 10.1016/j.cell.2011.09.036

Wu, S. J., Hsieh, T. J., Kuo, M. C., Tsai, M. L., Tsai, K. L., Chen, C. H., et al. (2013). Functional regulation of Alu element of human angiotensin-converting enzyme gene in neuron cells. Neurobiol. Aging 34, 1921-1927 e. doi: 10.1016/j. neurobiolaging.2013.01.003

Xia, P., Wang, S., Gao, P., Gao, G., and Fan, Z. (2016). DNA sensor cGAS-mediated immune recognition. Protein Cell 7, 777-791. doi: 10.1007/s13238-016-0 320-3

Xue, B., Sechi, L. A., and Kelvin, D. J. (2020). Human Endogenous Retrovirus K (HML-2) in Health and Disease. Front. Microbiol. 11:1690. doi: 10.3389/fmicb. 2020.01690
Young, G. R., Eksmond, U., Salcedo, R., Alexopoulou, L., Stoye, J. P., and Kassiotis, G. (2012). Resurrection of endogenous retroviruses in antibody-deficient mice. Nature 491, 774-778. doi: 10.1038/nature11599

Yousefian-Jazi, A., Seol, Y., Kim, J., Ryu, H. L., Lee, J., and Ryu, H. (2020). Pathogenic Genome Signatures That Damage Motor Neurons in Amyotrophic Lateral Sclerosis. Cells 9:2687. doi: 10.3390/cells9122687

Zhang, J. X., Joesoef, R. M., Bialek, S., Wang, C., and Harpaz, R. (2013). Association of physical trauma with risk of herpes zoster among Medicare beneficiaries in the United States. J. Infect. Dis. 207, 1007-1011. doi: 10.1093/infdis/j is 937

Zhang, Y., Li, T., Preissl, S., Amaral, M. L., Grinstein, J. D., Farah, E. N., et al. (2019). Transcriptionally active HERV-H retrotransposons demarcate topologically associating domains in human pluripotent stem cells. Nat. Genet. 51, 1380-1388. doi: 10.1038/s41588-019-0479-7

Zou, X., Chen, K., Zou, J., Han, P., Hao, J., and Han, Z. (2020). Single-cell RNAseq data analysis on the receptor ACE2 expression reveals the potential risk of different human organs vulnerable to 2019-nCoV infection. Front. Med. 14:185-192. doi: 10.1007/s11684-020-0754-0

Conflict of Interest: The author declares that the research was conducted in the absence of any commercial or financial relationships that could be construed as a potential conflict of interest.

Copyright (C) 2021 Römer. This is an open-access article distributed under the terms of the Creative Commons Attribution License (CC BY). The use, distribution or reproduction in other forums is permitted, provided the original author(s) and the copyright owner(s) are credited and that the original publication in this journal is cited, in accordance with accepted academic practice. No use, distribution or reproduction is permitted which does not comply with these terms. 